\title{
Impact of coral predators on tropical reefs
}

\author{
Randi D. Rotjan ${ }^{1,2, *}$, Sara M. Lewis ${ }^{1}$ \\ ${ }^{1}$ Department of Biology, Tufts University, Medford, Massachusetts 02155, USA \\ ${ }^{2}$ Present address: Organismic and Evolutionary Biology, Harvard University, Cambridge, Massachusetts 02138, USA
}

\begin{abstract}
It is well known that herbivores have numerous and diverse impacts on plant and algal fitness, community structure and ecosystem function. The importance of corallivory as a selective force, however, has been underestimated. Corallivores, or consumers of live coral tissue, employ a wide variety of feeding strategies and can be obligate or facultative coral feeders. Our literature review reveals a complex array of corallivores across the globe, represented by 11 families of fishes and 5 invertebrate phyla and totaling over 160 species known to consume scleractinian corals worldwide. Importantly, although these corallivores span a wide taxonomic range, we found that they have been reported to feed on relatively few genera of hard corals, specifically, on only 28 scleractinian genera worldwide. Damage by corallivores ranges from minor to lethal, but there is a growing body of evidence to support that even limited removal of tissue or skeletal structures has growth and/or fitness consequences for a scleractinian coral colony. In light of increasing reef stressors and diminishing coral populations, we suggest that the role of corallivores in reef trophodynamics is more complex than appreciated previously.
\end{abstract}

KEY WORDS: Coral reef resilience $\cdot$ Herbivory $\cdot$ Trophodynamics

Resale or republication not permitted without written consent of the publisher

\section{INTRODUCTION}

Coral reefs are among the most diverse ecosystems on earth, rivaled only by tropical rainforests in species diversity and abundance (reviewed by Reaka-Kudla 1997). Scleractinian corals are the major architects of tropical reefs, acting as ecosystem engineers (sensu Jones et al. 1994) and providing the structural framework for a highly diverse assemblage of marine organisms. It is well established that corals worldwide are increasingly threatened by abiotic stressors, including changes in seawater temperatures (Jokiel \& Coles 1977, 1990) and storms (Knowlton et al. 1990, Bythell et al. 1993, Alvarez-Filip \& Gil 2006). Likewise, much attention has been given to other stressors, including overfishing (Myers \& Worm 2003) and disease (Sutherland et al. 2004), which can be caused by biotic or abiotic factors and also contribute to coral reef decline. Direct consumption of live coral, or corallivory, represents another biotic stressor that can adversely affect coral fitness and accelerate rates of coral decline (Knowlton et al. 1990, Rotjan et al. 2006), yet little attention has been paid to the role corallivores might play in maintaining or conserving coral reef ecosystems.

Judging the impact of corallivory on tropical reefs has been controversial because many corallivores cause little apparent damage to corals, although a few species are known to cause severe damage. A variety of organisms consumes living coral, including fishes, annelids, crustaceans, echinoderms, and mollusks. Previous reviews on corallivory by Carpenter (1997), Glynn (1990b), and Robertson (1970) have focused mainly on invertebrates. Robertson (1970) provides an excellent description of corallivorous prosobranch gastropods. Hixon (1997) reviewed both direct and indirect effects of fishes on corals, including corallivorous butterflyfish, whose feeding habits have been well described (e.g. Harmelin-Vivien 1989). Even though most general discussions of reef trophic interactions have ignored the importance of corallivory, the identities and impacts of corallivores have been carefully investigated for a few specific locations, such as in the Galapagos (Glynn et al. 
1983) and Panama (Glynn et al. 1972, Glynn 2004). However, because no comprehensive review of the impact of corallivores on tropical reefs exists, the importance of corallivory as a selective force has likely been underestimated.

In this review, we provide a comprehensive description of known vertebrate and invertebrate corallivores, their foraging modes, and their rates of coral consumption. Since scleractinian corals are considered to be the major reef-builders, we focus exclusively on scleractinian corallivores. We describe major shifts in the relative importance of different corallivore groups across biogeographic regions. We provide a categorization of major predators as obligate versus facultative coral feeders, and examine whether they specialize on particular scleractinian coral genera. We review evidence concerning the impact of corallivory on the growth and fitness of reef-building corals. We conclude by discussing critical areas for future research necessary for an understanding of the changing role of corallivores and corallivory in reef trophodynamics and reef resilience.

\section{CLASSIFICATION OF CORALLIVORE FEEDING STRATEGIES}

Corallivores differ in their feeding strategies, with different consequences for coral prey. 'Mucus-feeders' consume only coral mucus without removing any other live coral tissue or underlying skeleton. Corallivores that remove coral tissue without damaging the underlying calcium carbonate skeleton are known as 'browsers' (Hiatt \& Strasburg 1960). Bellwood \& Choat (1990) distinguished two feeding modes for parrotfish that we apply here to all corallivores: 'excavators', which feed by removing live coral tissue with major portions of the underlying skeleton, and 'scrapers' , which remove live coral tissue while taking only little of the accompanying skeleton. These four categories can be used to classify the feeding strategies used by a wide variety of invertebrates and fish corallivores.

Some corallivores may also act as bioeroders (consumers of dead coral substrate), and these terms are sometimes used interchangably. However, this distinction is important because corallivores directly affect live coral and so are likely to have stronger effects on coral fitness. Bioeroders are known to play an important role in coral reef dynamics, re-shaping reef topography by eroding dead skeletons of mound-building corals, and weakening colony structure of live branching corals (reviewed by Hutchings 1986, Sammarco 1996). However, because bioeroders do not consume live coral tissue, they are not considered further in this review.

\section{MAJOR VERTEBRATE CORALLIVORES}

The first evidence of vertebrate corallivory was provided by Darwin (1842) from the HMS 'Beagle' in the Indian Ocean, where he recovered live coral from the stomachs of two Scarus parrotfish species. However, vertebrate corallivory received little attention until Cousteau (1952) made detailed behavioral observations of parrotfish feeding on live corals. Since then, accumulated studies have reported 114 species of vertebrates, representing 11 families of osteichthyan fishes, known to at least occasionally consume live corals (Appendix 1). The corals most commonly grazed by fishes include the genera Acropora, Pocillopora, Montipora, and Porites. Interestingly, we found that only 18 of the 111 known coral genera (listed in Veron 2000 ), a mere $16.2 \%$, have been reported to be even occasionally consumed by corallivorous fishes (Appendix 1). This suggests that either observational data are incomplete, or that many coral genera have evolved effective means of deterring predation.

Vertebrate corallivores use each of the coral feeding strategies described above (see also Appendix 1). Approximately half of the 114 corallivorous fishes are butterflyfishes (Chaetodontidae), browsers that remove individual coral polyps with long, fleshy lips (Motta 1988, 1989) without damaging the underlying skeleton. In contrast, all other piscine corallivores such as parrotfish, puffers, triggerfish, filefish, wrasses, and damselfish have the ability to remove skeletal material along with coral tissue, and thus are either excavators or scrapers. The feeding habits of Indo-Pacific parrotfishes have been relatively well studied (Bellwood \& Choat 1990), and corallivory is restricted to a few large excavating species that possess jaw structures capable of exerting large forces on their cutting edge. Caribbean parrotfish use two distinct grazing behaviors called focused biting and spot-biting (Bruckner et al. 2000): in the former, individual fish repeatedly bite a single area, resulting in extensive coral tissue and skeletal loss (Fig. 1A), whereas in the latter, feeding consists of shallow bites that are widely scattered over the colony surface (Fig. 1B). Identifying grazing scars can be difficult; both focused and spotbiting scars have been mistaken for disease lesions (Bruckner \& Bruckner 1998a,b, 2000). Although focused biting (Fig. 1C) on live coral has been implicated in territorial marking by adult terminal phase males of the stoplight parrotfish Sparisoma viride (Bruggemann et al. 1994, van Rooij et al. 1995), spotbiting does not appear to be associated with territoriality (Bruckner et al. 2000). Parrotfish grazing behavior may differ geographically, since focused biting is common in some Caribbean locations, e.g. Puerto Rico (Bruckner \& Bruckner 1998c), but comparatively rare 

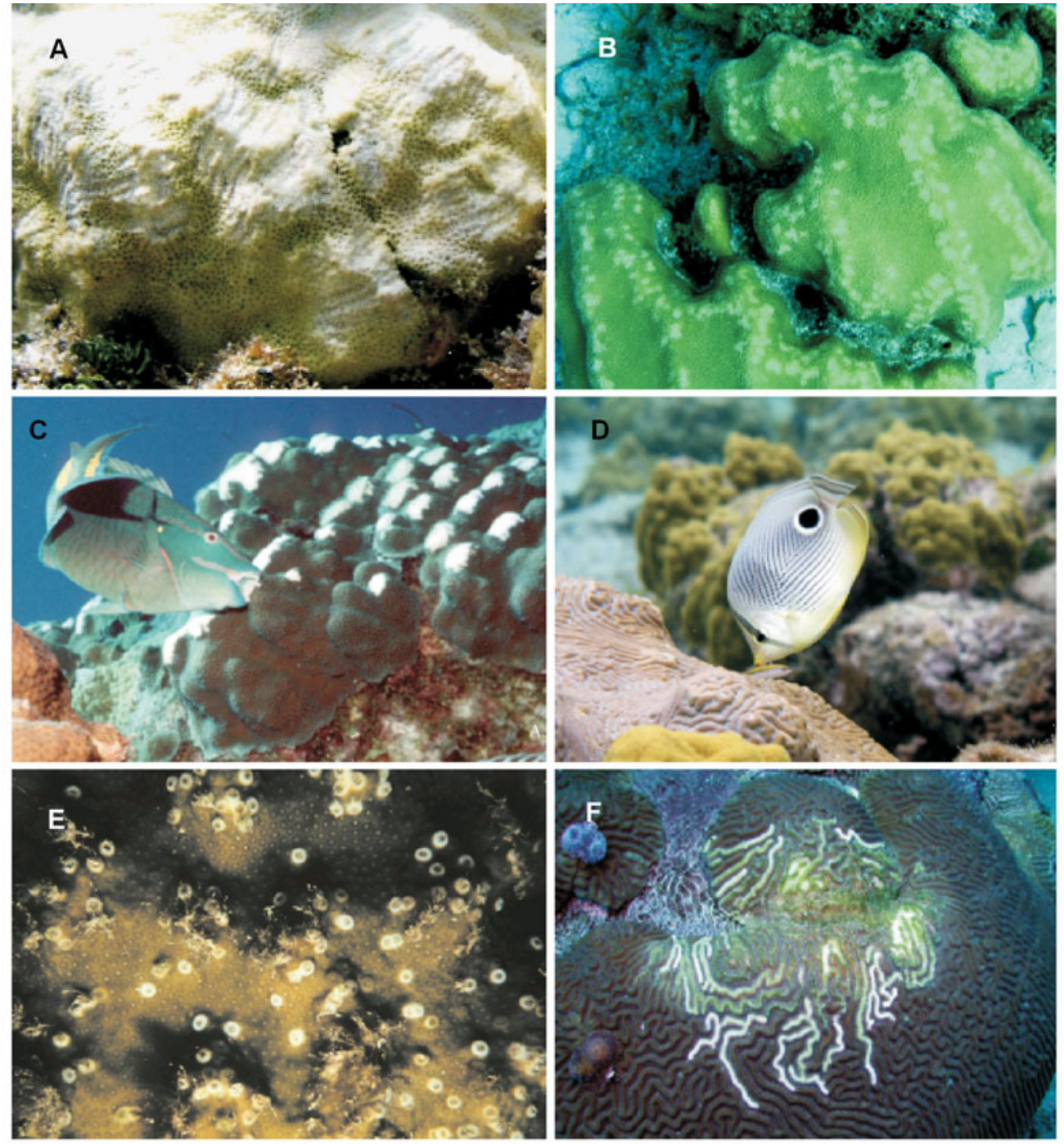

Fig. 1. Grazing impacts of Caribbean vertebrate corallivores. (A) Focused biting by the parrotfish Sparisoma viride on a Porites astreoides colony in a Belizean backreef habitat (image by R. Rotjan). (B) Spot-biting by S. viride on Montastraea spp. corals off Belize (image by R. Rotjan). (C) Terminal-phase $S$. viride in the act of grazing $M$. franksi (image by A. Bruckner). (D) The foureye butterflyfish (Chaetodon capistratus) grazing on a Diploria clivosa colony off Belize (image by R. Rotjan). (E) Chimneys on a Montastraea colony caused by damselfish grazing (image by A. Bruckner). (F) Algal garden growing on Colpophyllia natans after Stegastes damselfish have removed live coral tissue in the Flower Garden Banks in the Gulf of Mexico (image by E. Borneman)

in others, e.g. Belize (reported only for a single coral species by Rotjan \& Lewis 2005).

The Indo-Pacific giant humphead parrotfish Bolbometopon muricatum is by far the largest consumer of live coral tissue and skeletal material, although it is a facultative corallivore. It has been estimated that a B. muricatum population can consume $13.5 \mathrm{~kg}$ live coral $\mathrm{m}^{-2} \mathrm{yr}^{-1}$ (Bellwood et al. 2003). These parrotfish also contribute to reef bioerosion, breaking down $>5 \mathrm{t}$ of structural reef carbonates per year (Bellwood et al. 2003). Although largely non-selective, B. muricatum avoids Montipora species (Hoey \& Bellwood 2008) and instead prefers fast-growing acroporid and pocillo- porid corals (Bellwood et al. 2003), and thus may help to promote overall coral diversity by maintaining space for slower-growing coral species. This parrotfish species is likely to have a large influence on coral growth, mortality, and reproductive fitness, although additional studies are needed to investigate its ecological role on Pacific reefs.

Butterflyfishes are also major coral predators (Fig. 1D), consuming tissue but generally not removing coral skeleton (Randall 1967, Randall et al. 1996, Randall 2005). Many butterflyfishes remove single coral polyps using small forceps-like mouths, whereas others scrape coral mucus and polyps with wide, shovel-shaped 
mouths (Motta 1988). Overall, 53 species of butterflyfish are known to consume live coral, and 14 of these are obligate coral-feeders. Consumption rates vary among species, but average 7 bites $\mathrm{min}^{-1}$. Chaetodontids consume a wide variety of coral genera, but appear to focus on Porites, Acropora, Agaricites, Pocillopora, and Montipora corals (Appendix 1). Many butterflyfish are also highly territorial (Roberts \& Ormond 1992) and graze coral colonies within their territories repeatedly (Reese 1989, Roberts \& Ormond 1992). This chronic tissue removal might be expected to deplete colony resources, reducing nutrient content, growth, and reproductive output, although the effects of chronic butterflyfish corallivory have yet to be studied in detail for scleractinians. There are some data showing butterflyfish can remove substantial biomass and lower reproductive output in gorgonian corals (Lasker 1985). For example, in the San Blas Islands, Panama, Chaetodon capistratus was estimated to remove an average of 378 polyps $\mathrm{d}^{-1}$ from the gorgonian Plexaura homomalla and 100 polyps $\mathrm{d}^{-1}$ from Pseudopterogorgia americana gorgonians. At some sites, C. capistratus selectively grazed Plexaura spp. colonies with ripe gonads (Lasker 1985). It is known that, among scleractinians, the butterflyfish $C$. unimaculatus has a major influence on the abundance and distribution of Montipora verrucosa in Hawaii; caging experiments demonstrate that $C$. unimaculatus feeding restricts vertical growth of those corals (Cox 1986). Similarly, growth, zonation, and distribution of Pocillopora damicornis in Guam are impacted by piscine corallivores; transplant experiments suggest that these corals are restricted to shallow lagoon habitats due to feeding by chaetodontid and balistid fishes (Neudecker 1979). Nonetheless, several studies have documented a positive relationship between the density of obligate corallivorous butterflyfish and coral cover of their preferred prey species (Cox 1994, Findley \& Findley 2001), suggesting that frequent tissue removal by butterflyfish does not necessarily impact coral fitness negatively.

Damselfishes are also highly territorial, but they remove coral tissue mainly to promote growth of algal gardens (Fig. 1E,F) (Kaufman 1977), which these fish use for food and mate-attraction (Randall 1967, Brawley \& Adey 1977). Grazing by the damselfish Stegastes (formerly Eupomacentrus) planifrons on acroporid corals promotes coral skeletal growth into a distinctive, chimney-like structure characterized by a rounded lip on a raised column (Fig. 1E) (Kaufman 1977). Similar structures have been found on Pleistocene acroporid fossils, implying that damselfish biting live coral is not a recent phenomenon (Kaufman 1981). S. planifrons is known to cause ridge mortality on Diploria spp. corals (Proppe 1998), as well as partial mortality in Acropid coral fragments (Bruckner \& Bruckner 2001). Colony areas where damselfish have removed coral tissue are subsequently colonized by algal turf and macroalgae, which may have consequences for corals beyond tissue loss and energy needed for repair. Faster-growing algae compete with corals for light and space (reviewed by McCook et al. 2001), and direct contact with algae can enhance harmful microbial activity (Smith et al. 2006) and trigger coral disease (Nugues et al. 2004). On the other hand, damselfish aggressively guard their algal mats from herbivores, and this territorial behavior often deters grazing by corallivores as well (Glynn et al. 1983).

\section{MAJOR INVERTEBRATE CORALLIVORES}

There are 51 known species of invertebrate corallivores, including annelids, arthropods, echinoderms and mollusks; of these, only 16 are known to be obligate corallivores (Appendix 1). Invertebrates employ a range of strategies for feeding on coral (Fig. 2). Crabs of the genera Tetralia and Trapezia consume mostly coral mucus (Stimson 1990). Such mucus removal is not likely to have major negative effects as corals regularly slough off mucus into the water column, although mucus-feeding has been shown to disrupt coral microbial communities (Ducklow \& Mitchell 1979). Other invertebrate browsers on corals include the crown-ofthorns seastar Acanthaster planci, which feeds by everting its stomach to digest coral tissue without damaging skeletons (Fig. 2A) (Birkeland \& Lucas 1990). Many other invertebrate corallivores, for example the sea urchin Eucidaris thouarsii in Panama (Glynn et al. 1983), are scrapers that contribute to reef bioerosion by removing both tissue and underlying coral skeleton.

Among invertebrate predators, the seastar Acanthaster planci is perhaps the most influential. On Pacific reefs, it periodically reaches high population densities capable of destroying large reef tracts (Pearson \& Endean 1969, Moyer et al. 1982, Moran 1986, Colgan 1987, Birkeland \& Lucas 1990, Turner 1994, Cumming 1999). The causative factors responsible for these population outbreaks are not well-understood, although this has been the subject of much research (Vine 1971, Birkeland 1982, Birkeland \& Lucas 1990, Houk et al. 2007). Hypotheses for these outbreaks abound and include over-fishing, pesticide use, atomic testing, rain forest depletion, global climate change, and over-population (reviewed by Sapp 1999). Regardless of the cause, it has been estimated that a single A. planci individual can consume 5 to $6 \mathrm{~m}^{2}$ live coral $\mathrm{yr}^{-1}$ (Birkeland 1989), and densities during outbreaks can reach 4 to 6 ind. $\mathrm{m}^{-2}$ (reviewed by Carpenter 1997). A. planci aggregations often cause nearly $100 \%$ coral mortality in a localized area (reviewed by Carpenter 1997). A. planci is a facultative corallivore that prefer- 

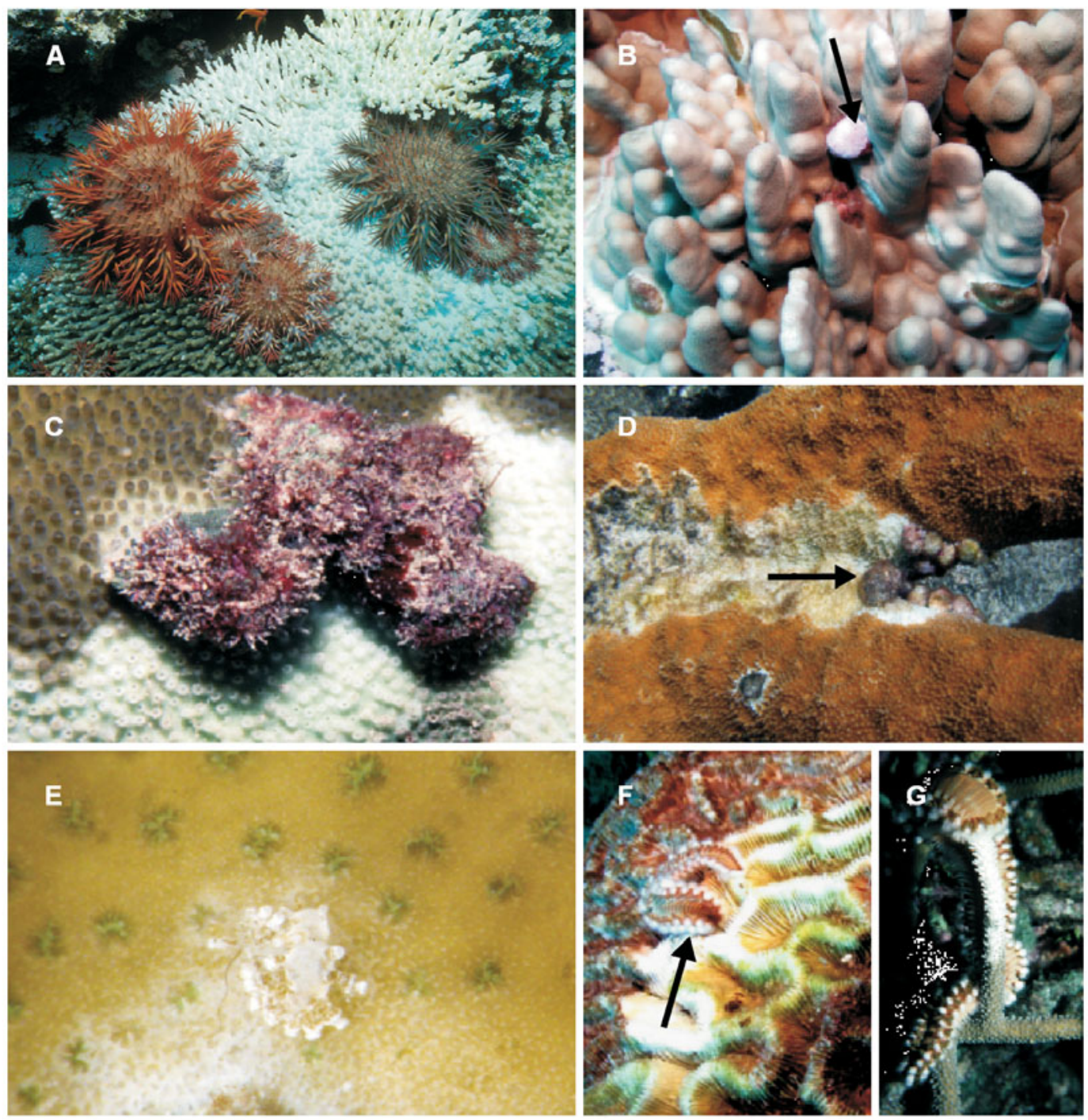

Fig. 2. Grazing on corals by various invertebrate corallivores. (A) Extensive coral tissue removal by Acanthaster planci (white coral skeleton remaining) off Tiran Island, Egypt (image by B. Furlan). (B) Snails of Drupella spp. feeding on live coral off Palau (image by E. Borneman). (C) Coralliophila abbreviata feeding on Acropora palmata colonies (image by A. Bruckner). (D) C. abbreviata corallivory off Mona Island, Puerto Rico (image by E. Borneman). (E) Nudibranch feeding on Montipora digitata tissue (image by E. Borneman). (F) Hermodice carunculata fireworm feeding on a Diploria spp. coral colony off Mona Island, Puerto Rico (image by E. Borneman). (G) H. carunculata feeding on an Acropora cervicornis colony (image by A. Bruckner). Arrows in B,D,F point to corallivores

entially consumes Pocillopora corals in Hawaii (Chess et al. 1997), but prefers Montipora and Acropora coral species almost everywhere else (Colgan 1987, Pratchett 2001). Following a large outbreak in Guam, A. planci prey preferences influenced reef community dynamics by temporarily shifting coral dominance to non-preferred corals (such as Porites spp. and Leptastrea spp.) until the reef recovered (Colgan 1987). Corallivorous snails of the genus Drupella (Fig. 2B) also periodically form aggregates of thousands of individuals (reviewed by Moyer et al. 1982 and Turner 1994). Drupella spp. are obligate corallivores that specialize on acroporid corals, primarily fast-growing
Acropora and Montipora spp. (Morton et al. 2002). Aggregations of Drupella spp. consumed an area of live coral covering $35 \mathrm{~m}^{2}$ in Toga Bay, Japan, over a period of $2 \mathrm{mo}$, and were considered responsible for a $35 \%$ decline in live coral cover over 2 yr (reviewed by Turner 1994). Due to a Drupella spp. outbreak on Ningaloo Reef (Western Australia), live coral cover was reduced by up to $86 \%$ in some reef habitats in less than a decade (Ayling \& Ayling 1987). Thus, localized population outbreaks of both $A$. planci and Drupella spp. can rapidly and severely reduce coral survival, although some reefs subsequently recover (e.g. Glynn 1973, Colgan 1987). 
In the Caribbean, the snail Coralliophila abbreviata appears to be an obligate coral feeder, since even after starvation, this corallivore would not consume algae, fish, or crustacean tissue (Ward 1965). C. abbreviata is known to consume 26 species of scleractinian coral (Miller 1981, Bruckner 2000), and is commonly found feeding on Acropora (Fig. 2C,D), Agaricia, and Montastraea spp. (Hayes 1990a, Bruckner 2000, Miller 2001, Baums et al. 2003). However, C. abbreviata does not seem to prefer one coral prey species over another (Hayes 1990b). Abiotic stressors, such as hurricanes, have been shown to concentrate corallivore populations, resulting in localized areas of rapid and high acroporid coral mortality (Knowlton et al. 1990). Furthermore, corallivory by Coralliophila spp., combined with other reef stressors such as herbivore reduction and/or hurricanes lowers reef resilience and has been implicated in contributing to phase shifts from coraldominated to algal- dominated reefs (Knowlton et al. 1990).

On Galapagos reefs, the sea urchin Eucidaris thouarsii can reach densities of 10 to 50 ind. $\mathrm{m}^{-2}$ (Glynn et al. 1979), and these corallivores caused extensive coral mortality and reduced reef resilience during an El Niño event (Glynn 1990a). These urchins are facultative corallivores specializing on Pocillopora and Pavona species, but crustose coralline algae are another major dietary component (Glynn et al. 1983). E. thouarsii does not regularly consume live coral in regions outside the Galapagos, although occasional corallivory has been reported in Panama (Glynn et al. 1983).

In contrast to the uniformly negative effects of most corallivores, some invertebrate predators are mutualists that provide net benefits to corals. The xanthid crabs Tetralia and Trapezia spp. feed on mucus and coral tissue (Knudsen 1967, Stimson 1990, Rinkevich et al. 1991), but guard their acroporid and pocilloporid coral hosts against more damaging corallivores such as Acanthaster planci (Glynn 1980, 1987, Pratchett 2001). Pocilloporid corals guarded by crabs have greater chances of survival when exposed to predation by A. planci compared to corals experimentally deprived of their crustacean symbionts (Glynn 1983). The shrimp Alpheus lottini also defends its coral hosts while having little negative impact on corals because it consumes only mucus (Glynn 1980). Finally, crabs of the genus Trapezia also enhance coral health by clearing fine sediments from coral surfaces. Stewart et al. (2006) showed in a field study that, when mutualist crabs (Trapezia) were removed, 45 to $80 \%$ of Acropora hyacinthus and Pocillopora verrucosa died within a month. Corals hosting crabs experienced no mortality under the same conditions, grew faster, and had lower sediment load and less tissue bleaching compared to corals without crabs (Stewart et al. 2006).

\section{PATTERNS OF CORALLIVORY}

Looking broadly across biogeographic regions, vertebrate corallivores clearly outnumber invertebrate species in almost every region of the world (Fig. 3). Reefs in the Pacific and Indian Oceans have more corallivore species compared to the Caribbean. This circumtropical pattern of species diversity has been previously noted for butterflyfishes, which have similarly few species in the tropical Atlantic and Eastern Pacific than the Indo-Pacific (Findley \& Findley 1989). In addition, we found that reefs in the Indo-Pacific, Oceania, and along the Great Barrier Reef, Australia, host more obligate corallivore species than Atlantic reefs (Fig. 3), which can possibly be explained by the lower coral diversity and older reefs of the Atlantic (Veron 1995). Worldwide, the majority of 161 known corallivores are facultative coral feeders, with only $\sim 25 \%$ feeding exclusively on live coral (Table 1). However, although live coral constitutes only a minor portion of the diet for most species, even low levels of corallivory can have potentially major consequences for corals.

Corallivores can be either specialists, consuming mainly one or a few coral genera, or generalists, consuming many coral genera. For example, the crab Tetralia cavimana is found exclusively on Acropora spp. (Glynn 1987), whereas the parrotfish Sparisoma viride feeds on a variety of coral genera including Montastraea, Porites, Siderastraea, and Colpophyllia spp. (Bruckner \& Bruckner 1998c, Garzon-Ferreira \& Reyes-Nivia 2001, Reyes-Nivia et al. 2004, Rotjan \& Lewis 2006). With almost $100 \%$ overlap in preferred coral genera between invertebrates and vertebrates, it appears that corallivores across the globe selectively feed on only a few coral families. Thus, all corallivores may be considered specialists to some degree because most coral species are avoided.

\section{CONSEQUENCES OF CORALLIVORY}

\section{Coral growth}

Corallivory causes coral tissue damage and/or loss, which can have direct negative effects on coral colony growth and survival. First, tissue loss requires reallocation of resources to tissue regeneration at the expense of new colony growth (reviewed by Henry \& Hart 2005). Colonies respond to damage by initiating regeneration and repair, which is very energy intensive for neighboring polyps (Meesters et al. 1994), and probably for the colony as a whole (Henry \& Hart 2005). In Montastraea annularis, $1 \mathrm{~cm}^{2}$ of artificial lesions suppressed colony growth by $32 \%$ over a 


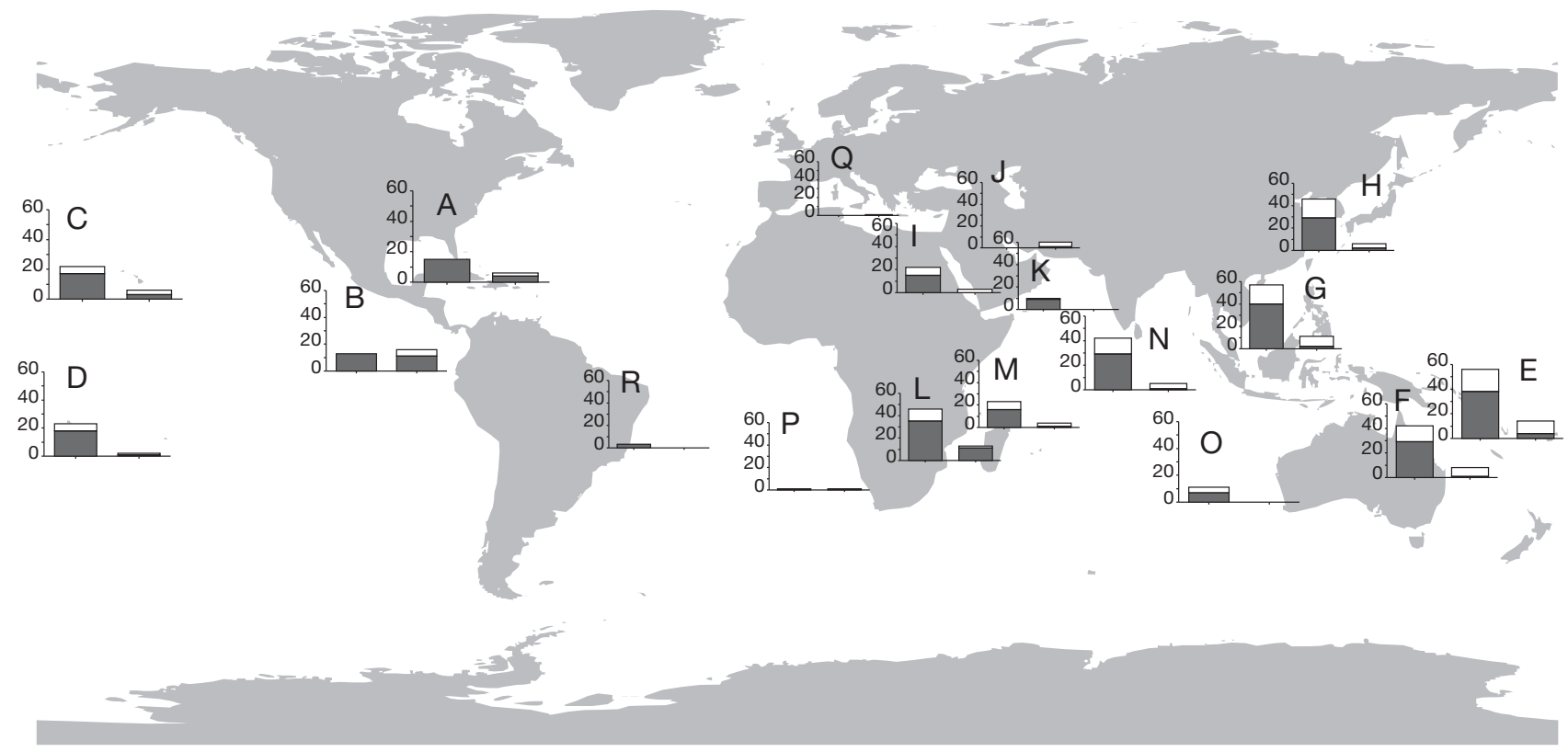

Fig. 3. Geographic distribution of corallivores. Stacked bars compare the number of obligate ( $\square$ ) to facultative ( $\square$ ) corallivorous species, either vertebrate (left bar) or invertebrate (right bar). $y$-axis on all graphs is no. of species. Letters represent geographic distribution of coral reef regions: (A) Caribbean and Bermuda, (B) Far Eastern Pacific (Galapagos and Panama), (C) Hawaii and the Johnston Atoll, (D) South Pacific (Tahiti, Pitcairn Islands, Marquesas), (E) Oceania (Guam, Micronesia, Marshall Islands American Samoa, French Polynesia, Cook Islands, Palau, Papua New Guinea, Fiji, New Caledonia, Tonga, Samoa, Solomon Islands, Palmyra Atoll, Jarvis Island, Tuvalu, Tokelau, Northern Mariana Islands), (F) Australia and the Great Barrier Reef, (G) Indo-Pacific (Cocos-Keeling Islands, Philippines, Singapore, Thailand, Indonesia, Malaysia, Paracel Islands), (H) Asian Pacific (Japan, South Korea, Taiwan, Hong Kong), (I) Red Sea, (J) Persian Gulf, (K) Arabian Sea (Oman), (L) AfricanIndian Ocean, (M) Southwest Indian Ocean (Seychelles, Mauritius, Reunion Islands), (N) Indian Ocean (Maldives, Sri Lanka, India), (O) Western Australia, (P) Southern Atlantic Ocean, (Q) Mediterranean Sea, (R) eastern South America (Brazil). Geographic distributions taken from Randall et al. (1996) and Randall (2005), and as specified by specific studies (Appendix 1) documenting incidents of corallivory. Note: Regions Q and P do have some corallivores, but literature about these regions is scarce, so we have reserved graph space to indicate that more corallivores are likely

2-mo regeneration period, and new growth continued to be suppressed for at least $30 \mathrm{~d}$ after regeneration stopped (Meesters et al. 1994). Considerably greater impacts on colony growth would be expected as a consequence of multiple tissue lesions (Henry \& Hart 2005), which is typically the case in piscine corallivory. Regeneration costs are related to lesion length or perimeter (the area bordering live tissue); regenerative capacity does not change with overall colony size (Meesters et al. 1994, Oren et al. 1997). Thus, even though larger colonies presumably have larger energy stores and more resources, the likelihood of recovery from damage is approximately equal among differently sized colonies.

Initial lesion size plays an important role in recovery potential, which is the likelihood that a coral will fully regenerate following tissue damage. For example, Porites astreoides in the Caribbean successfully repairs $1 \mathrm{~cm}^{2}$ lesions approximately $50 \%$ of the time, whereas it does not completely re-grow tissue over $5 \mathrm{~cm}^{2}$ lesions, either artificially-induced, or from parrotfish grazing (Bak \& Steward-Van Es 1980, Rotjan \& Lewis
2005). Other coral species recover more quickly or more fully from smaller lesions than from larger ones (Bak \& Steward-Van Es 1980, Lester \& Bak 1985, Oren et al. 1997, Croquer et al. 2002). In some cases, corals can completely recover from small grazing scars (e.g. Sanchez et al. 2004). Regeneration rates vary across coral species (Meesters et al. 1996), and are also dependent on environmental factors such as temperature (Lester \& Bak 1985, Meesters \& Bak 1993), depth (Meesters et al. 1997, Nagelkerken et al. 1999), location (Nagelkerken et al. 1999), and sedimentation rates (Croquer et al. 2002).

Lesion shape can also play an important role in recovery potential. Oren et al. (1997) found that removal of a single coral polyp (imitating butterflyfish feeding) leads to a $\sim 60 \%$ chance of recovery over a 90-d period. The same study also evaluated regeneration of tissue over parallel elongated lesions with 6 polyps removed per area and found $65 \%$ lesion recovery over $90 \mathrm{~d}$ (Oren et al. 1997). In theory, this parallel lesion pattern resembles scars from parrotfish grazing; however, these artificial lesions did not cause any 
skeletal damage, whereas real parrotfish feeding scars remove some portion of the underlying substrate. Strikingly, lesions resembling invertebrate grazing scars had the lowest recovery rate $(\sim 16 \%$ regenerated tissue over $90 \mathrm{~d}$ ). Thus, it seems that single-polyp, linear, and small $\left(\leq 2 \mathrm{~cm}^{2}\right)$ tissue-only lesions have best rates of regeneration, whereas circular or square lesions have the least (Bak \& Steward-Van Es 1980, Oren et al. 1997). Furthermore, tissue loss with accompanying skeletal damage has lower regenerative success than tissue damage alone (Bak \& Steward-Van Es 1980, Bak 1983, Croquer et al. 2002). These results suggest that any damage, even at the single-polyp level, initiates a regeneration procedure (with likely costs to overall colony growth or reproduction), and that regeneration of grazing scars is far from guaranteed. In the case of corallivory, tissue loss is likely to occur in multiple places on a colony simultaneously, and is likely to be chronic as many corallivores repeatedly graze the same colonies (Tricas 1989, Rotjan 2007). Thus, coral regeneration capabilities estimated from lesions inflicted at a single time point can give only a best-case scenario for tissue regeneration following the removal of tissue by corallivory.

\section{Coral reproduction}

Corallivory can also have direct consequences for coral reproductive potential (Henry \& Hart 2005). Corals have limited energy stores that are partitioned among growth, regeneration, and reproduction (Bak 1983, Harrison \& Wallace 1990). Energetically expensive reproduction is often compromised in favor of tissue regeneration processes (Szmant-Froelich 1985, Rinkevich \& Loya 1989, Harrison \& Wallace 1990, Van Veghel \& Bak 1994). Van Veghel \& Bak (1994) conducted a careful study of Montastraea annularis, M. faveolata, and M. franksi and found that colonies inflicted with artificial lesions $\sim 10$ wk prior to spawning showed a reduced reproductive effort (fertility, fecundity, fewer gonads per polyp, and fewer eggs per gonad) in neighboring polyps, compared to polyps located $20 \mathrm{~cm}$ away from the lesion area on the same colony. Furthermore, regenerated polyps had no reproductive activity, and polyps near regenerating tissue often had eggs of differing sizes (mature and immature), whereas distant polyps had only mature eggs (Van Veghel \& Bak 1994). Similarly, Rotjan (2007) examined Montastraea annularis corals that had been recently grazed by parrotfishes (within 1 wk of spawning) and found that parrotfish preferentially remove polyps with high reproductive potential (Rotjan 2007). Interestingly, they also found that intact portions of grazed colonies had fewer eggs per gonad and gonads per polyp than intact colonies (i.e. colonies without visible signs of corallivory). Since grazed colonies tend to be grazed repeatedly (Rotjan 2007), such chronic grazing requires constant regenerative efforts that would likely lead to lower reproduction rates. Taken together, these studies suggest that corallivory directly reduces coral reproduction by removing polyps with large numbers of mature eggs and gonads, and indirectly reduces reproduction in adjacent polyps which have to devote energy to tissue regeneration rather than reproduction.

\section{Indirect effects of corallivory}

Damage to colonies by corallivory can also have indirect consequences, such as the facilitation of algal competitors. Algal colonization does not necessarily prevent coral tissue regeneration, but unless regeneration occurs quickly, the likelihood of coral re-growth is severely reduced (Bak \& Steward-Van Es 1980, Bak 1983, Meesters \& Bak 1993, Oren et al. 1997). If a coral colony can complete the majority (at least $75 \%$ ) of its regeneration within the first $70 \mathrm{~d}$ following damage, full recovery is likely (Bak \& Steward-Van Es 1980). If tissue regeneration is incomplete, persisting portions of the colony become susceptible to colonization by spatial competitors such as algae, sponges, or other colonial invertebrates (e.g. zoanthids) (Bak \& StewardVan Es 1980). For example, artificial lesions on Montastraea cavernosa increased susceptibility to overgrowth by the encrusting sponge Rhaphidophlus venosus in Santa Marta, Columbia (Aerts 2000). Furthermore, the process of regeneration may hinder coral immune responses. Corals typically defend themselves against endolithic fungi by encapsulation; however, Bentis et al. (2000) found that, when acroprid and pocilloporid coral colonies were in the process of regenerating, they were less effective at preventing fungal infections. Future investigations might examine interactions between damage from corallivory and coral immunity to various diseases, as this is an issue likely to become increasingly important in coral reef conservation.

Although loss of coral tissue is the most obvious consequence of corallivory, corallivores can also negatively impact coral growth and fitness in other ways. The bearded fireworm Hermodice carunculata (Fig. 2F) is believed to serve as a vector for spreading coral disease agents, such as the bacterium Vibrio shiloi (Sussman et al. 2003). Similarly, field experiments in the Florida Keys have shown that the snail Coralliophila abbreviata infects Acropora palmata corals with white syndrome (Williams \& Miller 2005). The corallivorous nudibranch Phestilla spp. has also 
been implicated as a potential disease vector in Australia; following nudibranch grazing, coral fragments were colonized by various microbes, e.g. ciliates (Paramecium) and bacteria (Beggiatoa spp.), leading to subsequent epidermal tissue loss (Dalton \& Godwin 2006). Corallivorous fishes may also contribute to the spread of coral diseases. In laboratory studies, the Caribbean butterflyfish Chaetodon capistratus acted as a vector for black-band disease in the coral Montastraea faveolata via direct oral and/or indirect fecal transmission (Aeby \& Santavy 2006). Parrotfish grazing scars on Porites astreoides colonies in Belize sometimes develop disease bands around the margins (R. D. Rotjan pers. obs.), but no quantification of this effect has yet been published. It is likely that other corallivorous fish species serve as occasional vectors for disease, but this remains an area for future investigation.

Some corallivores additionally exploit their coral prey by sequestering nutrients and symbionts from corals as they feed. The nudibranch Phestilla sibogae is known to incorporate coral photosynthetic endosymbionts (dinoflagellate zooxanthellae of the genus Symbiodinium) (Haramaty 1991), and the coral-feeding barnacle Pyrgoma monticulariae stimulates coral tissue growth into its aperture to facilitate direct feeding on coral nutrients and defenses (Ross \& Newman 1969). This is not surprising, since many nudibranchs, sea hares, and other marine invertebrates are known to pilfer symbionts and defenses from a wide variety of prey, including Portuguese man o'war jellyfish, sponges, and soft corals (reviewed by Rudman 1986).

Some corallivores facilitate the destruction of corals by other corallivores. For example, predation by the gastropod Coralliophila abbreviata causes partial mortality in Acropora palmata colonies, and the feeding lesions then attract further corallivory by butterflyfish (Chaetodon striatus and C. ocellatus), which subsequently kills the colonies (Brawley \& Adey 1982). Clearly, corallivores facilitating further corallivory is of potentially great concern, and much work remains to be done to understand these cascading consequences.

\section{Synergies with other stressors}

Corallivory can act in synergy with other stressors to further reduce coral growth, regeneration, and reproductive potential. Additional stressors can be either chronic or acute, and either natural or anthropogenic. Although coral stressors are becoming both more numerous and more severe, the interaction between corallivory and other stressors has not been well studied. Knowlton et al. (1990) found in Jamaica that a suite of coral predators, the snail Coralliophila abbreviata, the polychaete Hermodice carunculata, the damselfish Stegastes planifrons, and the urchin Diadema antillarum significantly slowed the recovery of Acropora cervicornis after Hurricane Allen in 1980. Similarly, Rotjan et al. (2006) observed that chronic predation by parrotfishes on Montastraea spp. in Belize exacerbated the influence of abiotic stressors such as hurricanes and elevated seawater temperatures. Following a bleaching event in Belize, densities of zooxanthellae in colonies that had been grazed on by parrotfishes recovered slower, and their communities of zooxanthellae exhibited greater clade diversity (Rotjan et al. 2006). An interaction between partial colony mortality (functionally similar to corallivore grazing) and bleaching has also been demonstrated by Meesters and Bak (1993): they created artificial lesions on bleached and non-bleached Montastraea annularis colonies and found that bleached colonies exhibited less tissue growth, slower lesion recovery, slower tissue color restoration, and higher mortality. It is possible that coral reproduction may also be negatively affected by interactions between bleaching and corallivory, since bleaching (Szmant \& Gassman 1990) and corallivory (Szmant-Froelich 1985, Harrison \& Wallace 1990, Van Veghel \& Bak 1994, Rotjan 2007) have known reproductive fitness costs. Taken together, these studies indicate that the synergistic effects of corallivory with other stressors may be important, especially given that coral stressors are on the rise: 2005 was the hottest year in recorded history (Hansen et al. 2005), hurricanes are increasing in intensity (Hoyos et al. 2006), and overfishing is contributing to the regular collapse of ecosystem food webs (Jackson et al. 2001). Much research remains to be done on the interaction of multiple stressors and their additive or synergistic consequences.

\section{THE HERBIVORY-CORALLIVORY BALANCE}

Corallivory, though destructive, has not historically been responsible for the collapse of coral reef ecosystems. Yet, as coral cover continues to decline (Gardner et al. 2003, Pandolfi et al. 2003, Lesser 2004), corallivory may play a new role; instead of acting as a bioindicator of trouble (e.g. butterflyfish as bio-indicators of coral health), corallivores themselves may contribute to the problem. It should be noted that some common facultative corallivores, including scarid parrotfishes and the sea urchin Diadema antillarum, are also important herbivores. Herbivores are typically considered critical to the maintenance of healthy coral reefs (Hughes 1994), as their grazing activities indirectly benefit corals through preventing overgrowth by competitively superior macroalgae (Birkeland 1977 , Lewis 1986, McClanahan \& Muthiga 1998). Parrot- 
fishes are perhaps the most important components of this herbivorous fish fauna, regularly consuming epilithic and endolithic algae from dead carbonate substrates (Mumby 2006). Similarly, D. antillarum normally scrapes algae growing on calcium carbonate structures using an extendable chewing apparatus. Yet since some parrotfishes and $D$. antillarum also consume live coral, these grazers are likely to play a more complex role in reef dynamics than has been appreciated previously.

Important members of herbivorous fish guilds include scarids (parrotfishes), acanthurids (surgeonfishes) and kyphosids (chubs). Among these herbivores, there is some functional trophic redundancy, i.e. some species have partly overlapping diets. Because algal turfs and macroalgae grow so rapidly, some trophic redundancy can greatly enhance reef ecosystem dynamics, as herbivores can act jointly to control the abundance of certain algal species. The mass-mortality of the mainly herbivorous sea urchins of the genus Diadema in 1983, for example, did not initiate a phase-shift to algal-dominated reefs in those regions where functionally redundant, herbivorous fishes were abundant (Bak et al. 1984). The resulting conservation philosophy has thus been to promote trophic redundancy by preserving all members of the herbivorous reef community (Mumby 2006, Mumby et al. 2006).

When major herbivores such as parrotfish and urchins also consume live coral, their role in reef trophodynamics becomes more complex. In the case of the Pacific parrotfish Bolbometopon muricatum, corallivory may keep fast-growing, weedy coral species in check, although the specific ecological role of $B$. muricatum has not yet been examined. In a healthy Caribbean reef ecosystem, the amount of live coral consumed by parrotfishes and urchins appears unlikely to be detrimental to coral reef ecosystems. However, as live coral cover declines worldwide (Gardner et al. 2003, Pandolfi et al. 2003), the dual roles played by some parrotfishes and urchins as both herbivores and corallivores will need to be re-evaluated. Current models of marine protected areas (MPAs) that advocate the conservation of parrotfish have underestimated the multifaceted trophic role of these fishes (as in Mumby 2006, Mumby et al. 2006). Specifically, they have not yet taken into account the potential direct impact that some parrotfish species may have through their consumption of live coral; in other words, they have not yet considered the herbivory/corallivory balance. Future models of reef trophodynamics should investigate possible thresholds, based on live coral abundance, where exclusive conservation of non-corallivorous herbivores offers a greater benefit to coral survival rather than conservation of the entire guild of reef herbivores.

\section{THE INCREASING IMPORTANCE OF CORALLIVORY}

The role of corallivory in decreasing reef resilience has not yet been examined, but may play an important new role in reef decline. As coral reefs suffer record losses in live coral cover due to changing ocean temperatures (Hoegh-Guldberg 1999, Ostrander et al. 2000, Aronson et al. 2002, Hughes et al. 2003), increasing storm intensities (Hughes 1994, Hoyos et al. 2006), disease (Richardson 1998, Harvell et al. 1999, Harvell et al. 2002, Rosenberg \& Ben-Haim 2002, Sutherland et al. 2004), and increased pollution and eutrophication (Bell 1992, Lapointe 1997), the rate of coral decline may outpace the rate of corallivore decline. The relative impact of corallivory is likely to increase as coral cover decreases, with the potential for corallivory to negatively impact the fitness and survival of remaining reef corals. Future research is needed to re-evaluate the role of corallivores in reef trophodynamics and in reef-resilience models. Given that many facultative corallivores also play a major herbivorous role (e.g. parrotfishes, damselfishes, and the sea urchin Diadema antillarum), future studies might investigate the balance between beneficial herbivorous trophic contributions versus the detrimental corallivorous ones. Understanding this balance might help inform marine environmental managers about sustainable levels of corallivory, especially as live coral cover continues to decline.

Acknowledgements. We are grateful to E. Borneman, B. Furlan, and A. Bruckner for sharing their photographs. We also thank two anonymous reviewers, J. Chabot, J. Dimond, and M. Simon for their careful reading of this manuscript. B. Tavernia kindly procured the map used to generate Fig. 3. This work has also benefited from the continued support of K. Ruetzler, M. Carpenter, and the Smithsonian CCRE program, who have shown early and continued interest in parrotfish corallivory.

\section{LITERATURE CITED}

Acero AP, Rivera M (1992) Pecas de las familias Chaetodontidae y Pomacanthidae en la region de Santa Marta (Colombia): densidad y relacion con la Calidad del Arrecife. Caribb J Sci 28:184-190

Aeby GS, Santavy DL (2006) Factors affecting susceptibility of the coral Montastraea faveolata to black-band disease. Mar Ecol Prog Ser 318:103-110

Aerts LAM (2000) Dynamics behind standoff interactions in three reef sponge species and the coral Montastraea cavernosa. PSZNI Mar. Ecol 21:191-204

Allen GR, Randall JE (1977) Review of the sharpnose puffers (subfamily Canthigasterinae) of the Indo-Pacific. Rec Aust Mus 30:475-517

Alvarez-Filip L, Gil I (2006) Effects of hurricanes Emily and Wilma on coral reefs in Cozumel, Mexico. Coral Reefs 25: 583

- Alwany M, Thaler E, Stachowitsch M (2003) Food selection in two corallivorous butterflyfishes, Chaetodon austriacus 
and C. trifascialis, in the Northern Red Sea. PSZNI Mar Ecol 24:165-177

Aronson RB, Precht WF, Toscano MA, Koltes KH (2002) The 1998 bleaching event and its aftermath on a coral reef in Belize. Mar Biol 141:435-447

Ayling AM, Ayling AL (1987) Ningaloo Marine Park: preliminary fish density assessment and habitat survey. Report, Department of Conservation and Land Management by Sea Research, Daintree

Bak RPM (1983) Neoplasia, regeneration and growth in the reef-building coral Acropora palmata. Mar Biol 77:221-227

Bak RPM, Steward-Van Es Y (1980) Regeneration of superficial damage in the scleractinian corals Agaricia agaricites f. purpurea and Porites astreoides. Bull Mar Sci 30:883-887

Bak RPM, van Eys G (1975) Predation of the sea urchin Diadema antillarum Philippi on living coral. Oecologia 20: 111-115

Bak RPM, Carpay MJE, de Ruyter van Stevenink ED (1984) Densities of the sea urchin Diadema antillarum before and after mass mortalities on the coral reefs of Curacao. Mar Ecol Prog Ser 17:105-108

Barlow GW (1987) Spawning, eggs and larvae of the longnose filefish Oxymonacanthus longirostris, a monogamous coralivore. Environ Biol Fishes 20:183-194

Baums IB, Miller MW, Szmant AM (2003) Ecology of a corallivorous gastropod, Coralliophila abbreviata, on two scleractinian hosts. II. Feeding, respiration, and growth. Mar Biol 142:1093-1101

Bell PRF (1992) Eutrophication and coral reefs - some examples in the Great Barrier Reef lagoon. Water Res 26: 553-568

Bellwood DR (1995) Carbonate transport and within-reef patterns of bioerosion and sediment release by parrotfishes (family Scaridae) on the Great Barrier Reef. Mar Ecol Prog Ser 117:127-136

Bellwood DR, Choat JH (1990) A functional analysis of grazing in parrotfishes (Family Scaridae): the ecological implications. Environ Biol Fishes 28:189-214

Bellwood DR, Hoey AS, Choat JH (2003) Limited functional redundancy in high diversity systems: resilience and ecosystem function on coral reefs. Ecol Lett 6:281-285

Bentis CJ, Kaufman L, Golubic S (2000) Endolithic fungi in reef-building corals (Order: Scleractinia) are common, cosmopolitan, and potentially pathogenic. Biol Bull 198: 254-260

Birkeland CE (1977) The importance of rate of biomass accumulation in early successional stages of benthic communities to the survival of coral recruits. Proc 3rd Int Coral Reef Symp 1:15-21

Birkeland C (1982) Terrestrial runoff as a cause of outbreaks of Acanthaster planci (Echinodermata: Asteroidea). Mar Biol 69:175-185

Birkeland C (1989) The influence of echinoderms on coralreef communities. In: Jangoux M, Lawrence JM (eds) Echinoderm studies 3. Balkema, Rotterdam, p 1-79

Birkeland C, Lucas JS (1990) Acanthaster planci: major management problem of coral reefs. CRC Press, Boca Raton, FL

Bosch HF (1965) A gastropod parasite of solitary corals in Hawaii. Pac Sci 19:267-268

Brawley SH, Adey WH (1977) Territorial behavior of threespot damselfish (Eupomacentrus planifrons) increases reef algal biomass and productivity. Environ Biol Fishes 2: $45-51$

Brawley SH, Adey WH (1982) Coralliophila abbreviata: a significant corallivore! Bull Mar Sci 32:595-599

> Bruckner AW, Bruckner RJ (1998a) Rapid-wasting disease: pathogen or predator? Science 279:2019-2025
Bruckner AW, Bruckner RJ (1998b) Rapid wasting syndrome or coral predation by stoplight parrotfish? Reef Encounters 1998:18-22

Bruckner AW, Bruckner RJ (1998c) Destruction of coral by Sparisoma viride. Coral Reefs 17:350

Bruckner AW, Bruckner RJ (2000) Coral predation by Sparisoma viride and lack of relationship with coral disease. Proc 9th Int Coral Reef Symp 2:1245-1249

> Bruckner A, Bruckner R (2001) Condition of restored Acropora palmata fragments off Mona Island, Puerto Rico, 2 years after the Fortuna Reefer ship grounding. Coral Reefs 20:235-243

> Bruckner AW, Bruckner RJ, Sollins P (2000) Parrotfish predation on live coral: 'spot biting' and 'focused biting'. Coral Reefs 19:50

Bruckner RJ (2000) Effects of the population dynamics of the corallivorous prosobranch gastropod Coralliophila abbreviata (Lamarck) on coral tissue predation. Masters thesis, University of Puerto Rico Mayagüez, PR

> Bruggemann JH, Begeman J, Bosma EM, Verburg P, Breeman AM (1994) Foraging by the stoplight parrotfish Sparisoma viride. II. Intake and assimilation of food, protein, and energy. Mar Ecol Prog Ser 106:57-71

Bythell J, Bythell M, Gladfelter E (1993) Initial results of a longterm coral reef monitoring program: impact of hurricane Hugo at Buck Island Reef National Monument, St. Croix, U.S. Virgin Islands. J Exp Mar Biol Ecol 172:171-183

Carpenter RC (1997) Invertebrate predators and grazers. In: Birkeland C (ed) Life and death of coral reefs. Chapman \& Hall, New York, p 198-229

- Castro P (1978) Movements between coral colonies in Trapezia ferruginea (Crustacea: Brachyura), an obligate symbiont of scleractinian corals. Mar Biol 46:237-245

Chess JR, Hobson ES, Howard DF (1997) Interactions between Acanthaster planci (Echinodermata, Asteroidea) and scleractinian corals at Kona, Hawai'i. Pac Sci 51:121-133

Choat JH (1991) The biology of herbivorous fishes on coral reefs. In: Sale PF (ed) The ecology of coral reef fishes. Academic Press, New York, p 120-155

Colgan MW (1987) Coral reef recovery on Guam (Micronesia) after catastrophic predation by Acanthaster planci. Ecology 68:1592-1605

Cousteau JY (1952) Fish men explore a new world undersea. Natl Geogr Mag 102:432-472

> Cox EF (1986) The effects of a selective corallivore on growth rates and competition for space between two species of Hawaiian corals. J Exp Mar Biol Ecol 101:161-174

Cox EF (1994) Resource use by corallivorous butterflyfishes (family Chaetodontidae) in Hawaii. Bull Mar Sci 54: 535-545

Croquer A, Villamizar E, Noriega N (2002) Environmental factors affecting tissue regeneration of the reef-building coral Montastrea annularis (Faviidae) at Los Roques National Park, Venezuela. Rev Biol Trop 50:1055-1065

> Cumming RL (1999) Predation on reef-building corals: multiscale variation in the density of three corallivorous gastropods, Drupella spp. Coral Reefs 18:147-157

Dall WH (1889) Reports on the results of dredging, under the supervision of Alexander Agassiz, in the Gulf of Mexico, and in the Caribbean Sea, 1877-79, by the US Coast survey steamer Blake XXIV. Report on the Mollusca, Part II. Gastropoda and Scaphopoda. Bull Mus Comp Zool Harvard Univ 18:10-40

> Dalton SJ, Godwin S (2006) Progressive coral tissue mortality following predation by a corallivorous nudibranch (Phestilla sp.). Coral Reefs 25:529

Dana T, Wolfson A (1970) Eastern Pacific crown-of-thorns 
starfish populations in the lower Gulf of California. San Diego Soc Natur Hist, Trans 16:83-90

Darwin CR (1842) The structure and distribution of coral reefs. Smith, Elder \& Co, London

Ducklow HW, Mitchell R (1979) Bacterial populations and adaptations in the mucus layers on living corals. Limnol Oceanogr 24:715-725

Findley JS, Findley MT (1989) Circumtropical patterns in butterflyfish communities. Environ Biol Fishes 25:33-46

Findley JS, Findley MT (2001) Global, regional, and local patterns in species richness and abundance of butterflyfishes. Ecol Monogr 71:69-91

Francini-Filho RB, Moura RL, Ferreira CM, Coni EOC (2008) Live coral predation by parrotfishes (Perciformes: Scaridae) in the Abrolhos Bank, eastern Brazil, with comments on the classification of species into functional groups. Neotropical Ichthyology 6(2):191-200

Frydl P (1979) The effect of parrotfish (Scaridae) on coral in Barbados, W.I. Int Re Ges Hydrobiol 64:737-748

> Gardner TA, Cote IM, Gill JA, Grant A, Watkinson AR (2003) Long-term region-wide declines in Caribbean corals. Science 301:958-960

Garzon-Ferreira J, Reyes-Nivia MC (2001) Incidence of fish predation on stony corals at four atolls of the archipelago of San Andres and Providencia (Colombian Caribbean). Bol Inv Mar Cost 30:133-150

Glynn PW (1973) Acanthaster: effect on coral reef growth in Panama. Science 180:504-506

Glynn PW (1980) Defense by symbiotic crustacea of host corals elicited by chemical cues from predator. Oecologia 47:287-290

Glynn PW (1983) Increased survivorship in corals harboring crustacean symbionts. Mar Biol Lett 4:105-111

Glynn PW (1987) Some ecological consequences of coralcrustacean guard mutualisms in the Indian and Pacific Oceans. Symbiosis 4:301-324

Glynn PW (1988) El Niño warming, coral mortality and reef framework destruction by echinoid bioerosion in the Eastern Pacific. Galaxea 7:129-160

Glynn PW (1990a) Coral mortality and disturbances to coral reefs in the tropical eastern Pacific. In: Glynn PW (ed) Global ecological consequences of the 1982-83 El NiñoSouthern Oscillation. Elsevier, Amsterdam, p 55-126

Glynn PW (1990b) Feeding ecology of selected coral-reef macroconsumers: patterns and effects on coral community structure. In: Glynn PW (ed) Ecosystems of the world: coral reefs, Vol 25. Elsevier, Amsterdam, p 365-400

Glynn PW (2004) High complexity food webs in low-diversity eastern Pacific coral-reef communities. Ecosystems 7 : 358-367

Glynn PW, Krupp DA (1986) Feeding biology of a Hawaiian sea-star corallivore Culcita novaeguineae. J Exp Mar Biol Ecol 96:75-96

Glynn PW, Stewart R, McCosker J (1972) Pacific coral reefs of Panama: structure, distribution, and predators. Geol Rundsch 61:483-519

> Glynn PW, Wellington GM, Birkeland C (1979) Coral reef growth in the Galapagos: limitation by sea urchins. Science 203:47-49

Glynn PW, Wellington GM, Wells JW (1983) Corals and coral reefs of the Galapagos Islands. University of California Press, Berkeley, CA

Griffin SP, Garcia RP, Weil E (2003) Bioerosion in coral reef communities in southwest Puerto Rico by the sea urchin Echinometra viridis. Mar Biol 143:79-84

Guzman HM (1988) Feeding activity of the corallivorous gastropod Quoyula monodonta Blainville. Rev Biol Trop 36:
209-212

Hansen J, Ruedy R, Sato M, Lo K (2005) Global temperature trends: 2005 summation. NASA Goddard Institute for Space Studies, Greenbelt, MD

Haramaty L (1991) Reproduction effort in the nudibranch Phestilla sibogae: calorimetric analysis of food and eggs. Pac Sci 45:257-262

Harmelin-Vivien ML (1979) Ichtyofaune des recifs coralliens de Tulear (Madagascar): écologie et relations trophiques. $\mathrm{PhD}$ thesis, Université d'Aix-Marseille II, Marseille

> Harmelin-Vivien ML (1989) Implications of feeding specialization on the recruitment processes and community structure of butterflyfishes. Environ Biol Fishes 25:101-110

> Harmelin-Vivien ML, Bouchon-Navaro Y (1983) Feeding diets and significance of coral feeding among chaetodontid fishes in Moorea (French Polynesia). Coral Reefs 2:119-127

Harrison PL, Wallace CC (1990) Reproduction, dispersal and recruitment of scleractinian corals. In: Dubinsky Z (ed) Ecosystems of the world: coral reefs, Vol 25. Elsevier, Amsterdam

- Harvell CD, Kim K, Burkholder JM, Colwell RR and others (1999) Emerging marine diseases - climate links and anthropogenic factors. Science 285:1505-1510

Harvell CD, Mitchell CE, Ward JR, Altzier S, Dobson AP, Ostfield RS, Samuel MD (2002) Climate warming and disease risks for terrestrial and marine biota. Science 296: 2158-2162

Hayes JA (1990a) Distribution, movement and impact of the corallivorous gastropod Coralliophila abbreviata (Lamarck) on a Panamanian patch reef. J Exp Mar Biol Ecol 142:25-43

Hayes JA (1990b) Prey preference in a Caribbean corallivore, Coralliophila abbreviata (Lamarck) (Gastropoda, Coralliophilidae). Bull Mar Sci 47:557-560

> Henry L, Hart M (2005) Regeneration from injury and resource allocation in sponges and corals - a review. Int Rev Hydrobiol 90:125-158

Herring PJJ (1972) Observations on the distribution and the feeding habits of some littoral echinoids from Zanzibar. J Nat Hist 6:169-175

Hiatt RW, Strasburg DW (1960) Ecological relationships of the fish fauna on coral reefs of the Marshall Islands. Ecol Monogr 30:65-127

Hixon MA (1997) Effects of reef fishes on corals and algae. In: Birkeland C (ed) Life and death of coral reefs. Chapman \& Hall, New York, p 230-248

> Hoegh-Guldberg O (1999) Climate change, coral bleaching and the future of the world's coral reefs. Mar Freshw Res 50:839-866

Hoey AS, Bellwood DR (2008) Cross-shelf variation in the role of parrotfishes on the Great Barrier Reef. Coral Reefs 27: $37-47$

Houk P, Bograd S, Van Woesik R (2007) The transition zone chlorophyll front can trigger Acanthaster planci outbreaks in the Pacific Ocean: historical confirmation. J Oceanogr 63:149-154

> Hoyos CD, Agudelo PA, Webster PJ, Curry JA (2006) Deconvoluting of the factors contributing to the increase in global hurricane intensity. Science 312:94-97

Hughes TP (1994) Catastrophes, phase shifts, and large scale degradation of a Caribbean coral reef. Science 256: 1547-1551

> Hughes TP, Baird AH, Bellwood DR, Card M and others (2003) Climate change, human impacts, and the resilience of coral reefs. Science 301:929-933

> Hutchings PA (1986) Biological destruction of coral reefs: a review. Coral Reefs 4:239-252

Irons DK (1989) Temporal and areal feeding behavior of the 
butterflyfish, Chaetodon trifascialis, at Johnston Atoll. Environ Biol Fishes 25:187-193

Jackson JBC, Kirby MX, Berger WH, Bjorndal KA and others (2001) Historical overfishing and the recent collapse of coastal ecosystems. Science 293:629-637

Jayewardene D, Birkeland C (2006) Fish predation on Hawaiian corals. Coral Reefs 25:328

Jokiel PL, Coles SL (1977) Effects of temperature on the mortality and growth of Hawaiian reef corals. Mar Biol 43: 201-208

Jokiel PL, Coles SL (1990) Response of Hawaiian and other Indo-Pacific reef corals to elevated temperature. Coral Reefs 8:155-162

> Jones CG, Lawton JH, Shachak M (1994) Organisms as ecosystem engineers. Oikos 69:373-386

Kaufman L (1977) The three spot damselfish: effects on benthic biota of Caribbean coral reefs. Proc 3rd Int Coral Reef Symp 1:559-564

Kaufman L (1981) There was biological disturbance on Pleistocene coral reefs. Paleobiology 7:527-532

Keen AM (1958) Sea shells of tropical west America. Stanford University Press, Stanford, CA

Kita M, Kitamura M, Koyama T, Teruya $T$, Matsumoto $H$, Nakano Y, Uemura D (2005) Feeding attractants for the muricid gastropod Drupella cornus, a coral predator. Tetrahedron Lett 46:8583-8585

Knowlton N, Lang JC, Keller B (1990) Case study of natural population collapse: post-hurricane predation on Jamaica staghorn corals. Smithson Contrib Mar Sci 31:1-25

Knudsen JW (1967) Trapezia and Tetralia (Decapoda, Brachyura, Xanthidae) as obligate ectoparasites of pocilloporid and acroporid corals. Pac Sci 21:51-57

Kuiter RH, Debelius H (1999) Description of a new butterflyfish, Chaetodon andamanensis, from the eastern Indian Ocean (Pisces, Perciformes, Chaetodontidae). Senck Biol 79:231-235

Lapointe B (1997) Nutrient thresholds for bottom-up control of macroalgal blooms on coral reefs in Jamaica and southeast Florida. Limnol Oceanogr 42:1119-1131

Lasker HR (1985) Prey preferences and browsing pressure of the butterflyfish Chaetodon capistratus on Caribbean gorgonians. Mar Ecol Prog Ser 21:213-220

Lesser MP (2004) Experimental biology of coral reef ecosystems. J Exp Mar Biol Ecol 300:217-252

Lester RT, Bak RPM (1985) Effects of environment on regeneration rate of tissue lesions in the reef coral Montastrea annularis (Scleractinia). Mar Ecol Prog Ser 24:183-185

Lewis SM (1986) The role of herbivorous fishes in the organization of a Caribbean reef community. Ecol Monogr 56: 183-200

McClanahan TR, Muthiga NA (1988) Changes in Kenyan coral reef community structure and function due to exploitation. Hydrobiologia 166:269-276

McClanahan TR, Maina J, Starger CJ, Herron-Perez P, Dusek E (2005) Detriments to post-bleaching recovery of corals. Coral Reefs 24:230-246

> McCook LJ, Jompa J, Diaz-Pulido G (2001) Competition between corals and algae on coral reefs: a review of evidence and mechanisms. Coral Reefs 19:400-417

McIlwain JL, Jones GP (1997) Prey selection by an obligate coral-feeding wrasse and its response to small-scale disturbance. Mar Ecol Prog Ser 155:189-198

Meesters EH, Bak RPM (1993) Effects of coral bleaching on tissue regeneration potential and colony survival. Mar Ecol Prog Ser 96:189-198

> Meesters EH, Noordeloos M, Bak RPM (1994) Damage and regeneration: links to growth in the reef-building coral
Montastrea annularis. Mar Ecol Prog Ser 112:119-128

Meesters EH, Wesseling I, Bak RPM (1996) Partial mortality in three species of reef-building corals and the relation with coral morphology. Bull Mar Sci 58:838-852

> Meesters EH, Wesseling I, Bak RPM (1997) Coral colony tissue damage in six species of reef-building corals: partial mortality in relation with depth and surface area. J Sea Res 37:131-144

Miller AC (1981) Cnidarian prey of the snails Coralliophila abbreviata and C. caribaea (Gastropoda: Muricidae) in Discovery Bay, Jamaica. Bull Mar Sci 31:932-934

Miller MW (2001) Corallivorous snail removal: evaluation of impact on Acropora palmata. Coral Reefs 19:293-295

Moran PJ (1986) The Acanthaster phenomenon. Oceanogr Mar Biol Ann Rev 24:379-480

> Morton B, Blackmore G, Kwok CT (2002) Corallivory and prey choice by Drupella rugosa (Gastropoda: Muricidae) in Hong Kong. J Molluscan Stud 68:217-223

Motta PJ (1988) Functional morphology of the feeding apparatus of ten species of Pacific butterflyfishes (Perciformes, Chaetodontidae): an ecomorphological approach. Environ Biol Fishes 22:39-67

> Motta PJ (1989) Dentition patterns among Pacific and Western Atlantic butterflyfishes (Perciformes, Chaetodontidae): relationship to feeding ecology and evolutionary history. Environ Biol Fishes 25:159-170

Moyer JT, Emerson WK, Ross M (1982) Massive destruction of scleractinian corals by the muricid gastropod, Drupella, in Japan and the Philippines. Nautilus 96:69-82

> Mumby PJ (2006) The impact of exploiting grazers (Scaridae) on the dynamics of Caribbean coral reefs. Ecol Appl 16: 747-769

Mumby PJ, Dahlgren CP, Harborne AR, Kappel CV and others (2006) Fishing, trophic cascades, and the process of grazing on coral reefs. Science 311:98-101

- Myers RA, Worm B (2003) Rapid worldwide depletion of predatory fish communities. Nature 423:280-283

Nagelkerken I, Meesters EH, Bak RPM (1999) Depth-related variation in regeneration of artifical lesions in the Caribbean corals Porites astreoides and Stephanocoenia michelinii. J Exp Mar Biol Ecol 234:29-39

Neudecker S (1979) Effects of grazing and browsing fishes on the zonation of corals in Guam. Ecology 60:666-672

Neudecker S (1985) Foraging patterns of chaetodontid and pomacanthid fishes at St. Croix (U.S. Virgin Islands). Proc 5th Int Coral Reef Symp 5:415-420

> Nugues MM, Smith GW, van Hooidonk RJ, Seabra MI, Bak RPM (2004) Algal contact as a trigger for coral disease. Ecol Lett 7:919-923

> Oren U, Benayahu Y, Loya Y (1997) Effect of lesion size and shape on regeneration of the Red Sea coral Favia favus. Mar Ecol Prog Ser 146:101-107

> Oren U, Brickner I, Loya Y (1998) Prudent sessile feeding by the corallivore snail Coralliophila violacea on coral energy sinks. Proc R Soc Lond B Biol Sci 265:2043-2050

Ostergaard JM (1955) Some opisthobranchiate Mollusca from Hawaii. Pac Sci 9:110-136

Ostrander GK, Armstrong KM, Knobbe ET, Gerace D, Scully EP (2000) Rapid transition in the structure of a coral reef community: the effects of bleaching and physical disturbance. Proc Natl Acad Sci USA 97:5297-5302

> Pandolfi JM, Bradbury RH, Sala E, Hughes TP and others (2003) Global trajectories of the long-term decline of coral reef ecosystems. Science 301:955-958

Pearson RG, Endean R (1969) A preliminary study of the coral predator Acanthaster planci (L.) (Asteroidea) on the Great Barrier Reef. Fish Notes 3:27-55 
Pratchett MS (2001) Influence of coral symbionts on feeding preferences of crown-of-thorms starfish Acanthaster planci in the western Pacific. Mar Ecol Prog Ser 214:111-119

Proppe D (1998) Association of the threespot damselfish (Stegastes planifrons) in ridge mortality of Diploria strigosa in the Flower Garden Banks National Marine Sanctuary. Texas A\&M library. Spec Collect 1-22

Randall JE (1967) Food habits of reef fishes of the West Indies. In: Proceedings of the International Conference on Tropical Oceanography Nov 1965, Miami Beach, Florida. Studies in Tropical Oceanography 5:665-847

Randall JE (1974) The effect of fishes on coral reefs. Proc 2nd Int Coral Reef Symp 1:159-166

Randall JE (2005) Reef and shore fishes of the South Pacific: New Caledonia to Tahiti and the Pitcairn Islands. University of Hawaii Press, Honolulu, HI

Randall JE, Allen GR, Steene RC (1996) Fishes of the Great Barrier Reef and Coral Sea. University of Hawaii Press, Honolulu, HI

Reaka-Kudla M (1997) The global biodiversity of coral reefs: a comparison with rain forests. In: Reaka-Kudla M, Wilson DE, Wilson EO (eds) Biodiversity II: understanding and protecting our biological resources. Joseph Henry Press, Washington, DC, p 83-108.

Reese ES (1977) Coevolution of corals and coral feeding fishes of the family Chaetodontidae. Proc 3rd Int Coral Reef Symp 1:267-274

Reese ES (1989) Orientation behavior of butterflyfishes (family Chaetodontidae) on coral reefs: spatial learning of route specific landmarks and cognitive maps. Environ Biol Fishes 25:79-86

Reyes-Bonilla H, Calderon-Aguilera LE (1999) Population density, distribution and consumption rates of three corallivores at Cabo Pulmo reef, Gulf of California, Mexico. PSZNI Mar Ecol 20:347-357

Reyes-Nivia MC, Garzón-Ferreira J, Rodríguez-Ramírez A (2004) Depredación de coral vivo por peces en el Parque Nacional Natural Tayrona, Caribe colombiano. Rev Biol Trop 52:883-895

Richardson LL (1998) Coral diseases: what is really known. Trends Ecol Evol 13:438-443

Righton DA, Miller M, Ormond RG (1998) Correlates of territory size in the butterflyfish Chaetodon austriacus (Ruppell). J Exp Mar Biol Ecol 226:183-193

Rinkevich B, Loya Y (1989) Reproduction in regenerating colonies of the coral Stylophora pistilata. In: Spanier E, Steinberger Y, Luria M (eds) Environmental quality and ecosystem stability. Vol IV-B. Israel Society for Ecology and Environmental Quality Sciences, Jerusalem, p 257-265

Rinkevich B, Wolodarsky Z, Loya Y (1991) Coral-crab association: a compact domain of a multilevel trophic system. Hydrobiologia 216/217:279-284

Ritson-Williams R, Shjegstad S, Paul VJ (2003) Host specificity of four corallivorous Phestilla nudibranchs (Gastropoda: Opisthobranchia). Mar Ecol Prog Ser 255: 207-218

Roberts CM, Ormond RFG (1992) Butterflyfish social behaviour, with special reference to the incidence of territoriality: a review. Environ Biol Fishes 34:79-93

Robertson R (1970) Review of the predators and parasites of stony corals, with special reference to symbiotic prosobranch gastropods. Pac Sci 24:43-54

Robertson R, Scheltema RS, Adams FW (1970) The feeding, larval dispersal and metamorphosis of Philippia (Gastropoda: Architectonidae). Pac Sci 23:252-256

Rosenberg E, Ben-Haim Y (2002) Microbial diseases of corals and global warming. Environ Microbiol 4:318-326
Ross A, Newman WA (1969) A coral-eating barnacle. Pac Sci 23:252-256

Rotjan RD (2007) The patterns, causes, and consequences of parrotfish corallivory in Belize. Doctoral dissertation, Tufts University, Boston, MA

Rotjan RD, Lewis SM (2005) Selective predation by parrotfishes on the reef coral Porites astreoides. Mar Ecol Prog Ser 305:193-201

Rotjan RD, Lewis SM (2006) Parrotfish abundance and corallivory on a Belizean coral reef. J Exp Mar Biol Ecol 335: 292-301

Rotjan RD, Dimond JL, Thornhill DJ, Leichter JJ, Helmuth BST, Kemp DW, Lewis SM (2006) Chronic parrotfish grazing impedes coral recovery after bleaching. Coral Reefs 25:361-368

Rudman WB (1986) Nudibranchs: nature's thieves. Australian Nat Hist 22:2-6

Sadovy Y, Cornish AS (2000) Reef fishes of Hong Kong. Hong Kong University Press, Hong Kong

Sammarco PW (1996) Comments on coral reef regeneration, bioerosion, biogeography, and chemical ecology: future directions. J Exp Mar Biol Ecol 200:135-168

Sanchez JA, Gil MF, Chasqui LH, Alvarado EM (2004) Grazing dynamics on a Caribbean reef-building coral. Coral Reefs 23:578-583

Sano M, Shimizu M, Nose Y (1984) Food habits of teleostean reef fishes in Okinawa Island, Southern Japan. University of Tokyo Press, Tokyo

Sapp J (1999) What is natural? Coral reef crisis. Oxford University Press, New York

> Smith JE, Shaw M, Edwards RA, Obura D and others (2006) Indirect effects of algae on coral: algae-mediated, microbe-induced coral mortality. Ecol Lett 9:835-845

Stewart HL, Holbrook SJ, Schmitt RJ, Brooks AJ (2006) Symbiotic crabs maintain coral health by clearing sediments. Coral Reefs 25:609-615

Stimson J (1990) Stimulation of fat-body production in the polyps of the coral Pocillopora damicornis by the presence of mutualistic crabs of the genus Trapezia. Mar Biol 106: 211-218

> Sussman M, Loya Y, Fine M, Rosenberg E (2003) The marine fireworm Hermodice carunculata is a winter reservoir and spring-summer vector for the coral-bleaching pathogen Vibrio shiloi. Environ Microbiol 5:250-255

Sutherland KP, Porter JW, Torres C (2004) Disease and immunity in Caribbean and Indo-Pacific zooxanthellate corals. Mar Ecol Prog Ser 266:273-302

> Szmant AM, Gassman NJ (1990) The effects of prolonged 'bleaching' on the tissue biomass and reproduction of the reef coral Montastrea annularis. Coral Reefs 8:217-224

Szmant-Froelich AM (1985) The effect of colony size on the reproductive ability of the Caribbean coral Montastrea annularis. Proc 5th Int Coral Reef Symp 4:295-300

Thomassin BA (1976) Feeding behaviour of the felt-, sponge-, and coral-feeder sea stars, mainly Culcita schmideliana. Helgol Mar Res 28:51-65

- Tricas TC (1989) Prey selection by coral-feeding butterflyfishes: strategies to maximize the profit. Environ Biol Fishes 25:171-185

Turner SJ (1994) The biology and population outbreaks of the corallivorous gastropod Drupella on Indo-Pacific reefs. Oceanogr Mar Biol Ann Rev 32:461-530

Van Rooij JM, Bruggemann JH, Videler JJ, Breeman AM (1995) Ontogenetic, social, spatial and seasonal variations in condition of the reef herbivore Sparisoma viride. Mar Biol 123:269-275

Van Veghel MLJ, Bak RPM (1994) Reproductive characteris- 
tics of the polymorphic Caribbean reef building coral Montastrea annularis. III. Reproduction in damaged and regenerating colonies. Mar Ecol Prog Ser 109:229-233

Veron JEN (1995) Corals in space and time: the biogeography and evolution of the scleractinia. University of New South Wales Press, Sydney

Veron JEN (2000) Corals of the world. Australian Institute of Marine Science, Townsville

Vine P (1971) Crown of thorns (Acanthaster planci) plagues: the natural causes theory. Atoll Res Bull 166:1-15

Ward J (1965) The digestive tract and its relation to feeding habits in the stenoglossan prosobranch Coralliophila abbreviata (Lamarck). Can J Zool 43:447-464

Williams DE, Miller MW (2005) Coral disease outbreak: pat- tern, prevalence and transmission in Acropora cervicornis. Mar Ecol Prog Ser 301:119-128

Witman JD (1988) Effects of predation by the fireworm Hermodice carunculata on milleporid hydrocorals. Bull Mar Sci 42:446-458

Wrathall TJ, Roberts CM, Ormond RFG (1992) Territoriality in the butterflyfish Chaetodon austriacus. Environ Biol Fishes 34:305-308

Yokochi H (2004) Predation damage to corals. In: Coral reefs of Japan, Ministry of the Environment and Coral Reef Society, Tokyo

Zekeria ZA, Dawit Y, Ghebremedhin S, Nasin M, Videler JJ (2002) Resource partitioning among four butterflyfish species in the Red Sea. Mar Freshw Res 53:163-168

Appendix 1. Global list of vertebrate and invertebrate species known to consume live coral. Letter denotations for regions correspond to the map in Fig. 3. Feeding modes: obligate corallivores (O) eat exclusively live coral; facultative corallivores (F) have mixed diets that include some living coral. Consumption rate information varies, depending on the literature available (Appendix 2). In general, the table lists either the amount of coral removed per day (in $\mathrm{g} \mathrm{or} \mathrm{cm}^{2}$ ), number of bites min ${ }^{-1}$, or $\%$ live coral in gut contents. Obligate corallivores for which there is no feeding information are assumed to have between 97 and $100 \%$ live coral found in gut contents. Feeding styles are classified based on the portion of coral removed: mucus (M), coral tissue (T), or skeleton (S). Coral prey are grouped by genera, listed with the first three letters of each genus. Numbers in parentheses represent the number of corallivores in each taxonomic grouping

\begin{tabular}{|c|c|c|c|c|c|c|}
\hline Taxa & Region & $\begin{array}{c}\text { Feeding } \\
\text { mode }\end{array}$ & $\begin{array}{l}\text { Consumption } \\
\text { rate }\end{array}$ & Style & Coral prey & $\begin{array}{l}\text { Literature } \\
\text { cited }\end{array}$ \\
\hline \multicolumn{7}{|l|}{ Invertebrates (51) } \\
\hline \multicolumn{7}{|l|}{ Annelida (1) } \\
\hline$\overline{\text { Hermodice }}$ carunculata & $\mathrm{A}, \mathrm{P}, \mathrm{Q}$ & F & $12.9 \mathrm{~cm}^{2} \mathrm{~d}^{-1}$ & $\mathrm{~T}$ & Acr, Mil, Ocu, Por & 1,2 \\
\hline \multicolumn{7}{|l|}{ Arthropoda, Crustacea (9) } \\
\hline Alpheus lottini & $\mathrm{B}, \mathrm{J}$ & $\mathrm{F}$ & & $\mathrm{M}$ & Poc & 3 \\
\hline Aniculus elegans & B & $\mathrm{F}$ & $1.24 \mathrm{~g}(\mathrm{dry} w \mathrm{w}) \mathrm{d}^{-1}$ & $\mathrm{~T}, \mathrm{~S}$ & Poc & 4 \\
\hline Calcinus obscurus & B & & & $\mathrm{T}, \mathrm{S}$ & & \\
\hline Pyrgoma monticulariae & $\mathrm{G}, \mathrm{M}, \mathrm{N}$ & $\mathrm{O}$ & & $\mathrm{T}$ & & 5 \\
\hline Tetralia glaberrima & $\mathrm{E}, \mathrm{F}, \mathrm{J}$ & $\mathrm{O}$ & & $\mathrm{T}, \mathrm{M}$ & Acr, Ser & 6 \\
\hline Tetralia cavimana & $\mathrm{F}, \mathrm{I}, \mathrm{J}$ & $\mathrm{O}$ & & $\mathrm{T}, \mathrm{M}$ & Acr & 7 \\
\hline Trapezia cymodoce & $\mathrm{B}, \mathrm{F}, \mathrm{G}, \mathrm{I}, \mathrm{J}$ & $\mathrm{O}$ & $1.3-1.5 \mathrm{~cm}^{2} \mathrm{~d}^{-1}$ & $\mathrm{~T}, \mathrm{M}$ & Poc, Sty & 6,8 \\
\hline T. ferruginea & $B, E, F, G, J$ & $\mathrm{O}$ & & $\mathrm{M}$ & Poc & $4,6,9$ \\
\hline Trizopagurus magnificus & B & $\mathrm{F}$ & $10.3 \mathrm{mg} \mathrm{d}^{-1}$ & $\mathrm{~T}, \mathrm{~S}$ & Poc & 4 \\
\hline \multicolumn{7}{|c|}{ Echinodermata, Asteroidea (10) } \\
\hline Acanthaster ellisii & $\mathrm{B}$ & F & $145 \mathrm{~cm}^{2} \mathrm{~d}^{-1}$ & $\mathrm{~T}$ & Pav, Poc, Por, Psa & 10 \\
\hline A. planci & $\mathrm{B}, \mathrm{E}, \mathrm{F}, \mathrm{G}, \mathrm{H}$ & $\mathrm{F}$ & $116-187 \mathrm{~cm}^{2} \mathrm{~d}^{-1}$ & $\mathrm{~T}$ & Acr, Gar, Monti, Poc & $11-15$ \\
\hline Culcita novaguinaeae & $\mathrm{C}, \mathrm{D}, \mathrm{E}, \mathrm{G}, \mathrm{N}$ & $\mathrm{F}$ & $28 \mathrm{~cm}^{2} \mathrm{~d}^{-1}$ & $\mathrm{~T}$ & Acr, Poc & 16 \\
\hline C. schmideliana & $\mathrm{L}$ & $\mathrm{F}$ & & $\mathrm{T}$ & Acr, Gal, Gon & 17 \\
\hline Echinaster purpureus & $\mathrm{L}$ & F & & M & Por & 17 \\
\hline Linckia laevigata & $\mathrm{L}$ & F & & M & Por & 17 \\
\hline Nardoa variolata & $\mathrm{L}$ & $\mathrm{F}$ & & $\mathrm{M}$ & Por & 17 \\
\hline Nidorellia armata & $\mathrm{B}$ & $\mathrm{F}$ & & $\mathrm{T}$ & Pav & 18 \\
\hline Pentaceraster cumingi & B & $\mathrm{F}$ & & $\mathrm{T}$ & Psa & 12 \\
\hline Pharia pyramidata & $\mathrm{B}$ & F & & $\mathrm{T}$ & Poc & 10,18 \\
\hline \multicolumn{7}{|c|}{ Echinodermata, Echinoidea (11) } \\
\hline Astropyga radiata & $\mathrm{L}$ & $\mathrm{F}$ & & $\mathrm{T}$ & & 19 \\
\hline Diadema antillarum & $\mathrm{A}$ & F & & $\mathrm{T}, \mathrm{S}$ & $\begin{array}{l}\text { Acr, Aga, Mad, } \\
\text { Monta, Por }\end{array}$ & 20,21 \\
\hline D. setosum & $\mathrm{L}$ & $\mathrm{F}$ & & $\mathrm{T}$ & & 19 \\
\hline Echinothrix calamaris & $\mathrm{L}$ & $\mathrm{F}$ & & $\mathrm{T}$ & & 19 \\
\hline Eucidaris thouarsii & $\mathrm{B}$ & F & $0.47-1.83 \mathrm{~g} \mathrm{~m}^{2} \mathrm{~d}^{-1}$ & $\mathrm{~T}$ & Pav, Poc & $11,18,22$ \\
\hline Echinometra mathaei & $E, L, M$ & F & & $\mathrm{T}$ & & 19 \\
\hline E. viridis & A & F & & $\mathrm{T}$ & & 23 \\
\hline Echinoneus cyclostomus & $\mathrm{L}$ & F & & $\mathrm{T}$ & & 19 \\
\hline Microcyphus rousseaui & $\mathrm{L}$ & $\mathrm{F}$ & & $\mathrm{T}$ & & 19 \\
\hline Stomopneustes variolaris & $\mathrm{L}$ & $\mathrm{F}$ & & $\mathrm{T}$ & & 19 \\
\hline Tripneustes gratillia & $\mathrm{L}$ & F & & $\mathrm{T}$ & & 19 \\
\hline
\end{tabular}


Appendix 1 (continued)

\begin{tabular}{|c|c|c|c|c|c|c|}
\hline Taxa & Region & $\begin{array}{l}\text { Feeding } \\
\text { mode }\end{array}$ & $\begin{array}{l}\text { Consumption } \\
\text { rate }\end{array}$ & Style & Coral prey & $\begin{array}{l}\text { Literature } \\
\text { cited }\end{array}$ \\
\hline \multicolumn{7}{|l|}{ Mollusca (20) } \\
\hline Aeolidia edmondsoni & $\mathrm{C}$ & $\mathrm{O}$ & & $\mathrm{T}$ & Por & 24 \\
\hline Phestilla melanobrachia & $\mathrm{E}, \mathrm{G}, \mathrm{F}$ & $\mathrm{O}$ & & & Tur & 25,26 \\
\hline P. minor & $\mathrm{E}, \mathrm{L}$ & $\mathrm{O}$ & & & Por & 27 \\
\hline P. sibogae (P. lugubris) & $C, E, F, G$ & $\mathrm{O}$ & $6.4 \mathrm{~cm}^{2} \mathrm{~d}^{-1}$ & $\mathrm{~T}$ & Por & 27,28 \\
\hline Coralliophilla abbreviata & A & $\mathrm{O}$ & $0.08-16 \mathrm{~cm}^{2} \mathrm{~d}^{-1}$ & $\mathrm{~T}$ & $\begin{array}{c}\text { Acr, Aga, Col, Dic, } \\
\text { Dip, Eus, Fav, Hel, Mad, } \\
\text { Mea, Monta Myc, Por Sic }\end{array}$ & d $29-32,83$ \\
\hline C. violacea & $D, E, G, N$ & & $0.25 \mathrm{~cm}^{2} \mathrm{~d}^{-1}$ & $\mathrm{~T}$ & Por & 25,33 \\
\hline C. caribaea & A & & & $\mathrm{T}$ & Acr, Por & 31,34 \\
\hline Drupella cornus & $\mathrm{C}, \mathrm{E}, \mathrm{F}, \mathrm{H}, \mathrm{I}, \mathrm{N}$ & $\mathrm{O}$ & $2.6 \mathrm{~cm}^{2} \mathrm{~d}^{-1}$ & $\mathrm{~T}$ & $\begin{array}{c}\text { Acr, Monti, Poc, Por, } \\
\text { Ser, Sty }\end{array}$ & $25,35-38$ \\
\hline D. elata & $\mathrm{G}, \mathrm{H}$ & $\mathrm{O}$ & & $\mathrm{T}$ & Acr, Monti, Poc, Por & 37,39 \\
\hline D. fragum & $\mathrm{E}, \mathrm{H}$ & $\mathrm{O}$ & & $\mathrm{T}$ & $\begin{array}{l}\text { Acr, Monti, Poc, } \\
\text { Ser, Sty }\end{array}$ & $35,37,39,40$ \\
\hline D. rugosa & $\mathrm{E}, \mathrm{F}, \mathrm{G}, \mathrm{H}$ & $\mathrm{O}$ & $137-229 \operatorname{min~d}^{-1}$ & $\mathrm{~T}$ & $\begin{array}{l}\text { Acr, Monti, Poc, } \\
\text { Ser, Sty }\end{array}$ & $37,39,40$ \\
\hline Epitonium ulu & $\mathrm{C}$ & & & $\mathrm{T}$ & Fun & 41 \\
\hline Habromorula spinosa & $\mathrm{H}$ & & & & & 42 \\
\hline Jenneria pustulata & $\mathrm{B}$ & $\mathrm{O}$ & $0.8 \mathrm{~g} \mathrm{~d}^{-1}$ & $\mathrm{~T}$ & Poc, Por, Sid & 4 \\
\hline Latiaxis hindsii & B & & & $\mathrm{T}$ & Poc & 18,43 \\
\hline Muricopsis zeteki & B & & & $\mathrm{T}$ & Poc & 18,43 \\
\hline Pedicularia decussata & A & & & $\mathrm{T}$ & Sol & 44 \\
\hline Philippia radiata & $\mathrm{C}$ & F & & $\mathrm{T}$ & Por & 45 \\
\hline Quoyula madreporarum & $\mathrm{B}, \mathrm{E}, \mathrm{G}, \mathrm{L}, \mathrm{M}, \mathrm{N}$ & $\mathrm{O}$ & & $\mathrm{T}$ & $\begin{array}{l}\text { Monti, Poc, Por, } \\
\text { Ser, Sty }\end{array}$ & 25,46 \\
\hline Q. monodonta & $\mathrm{B}, \mathrm{E}, \mathrm{M}$ & $\mathrm{O}$ & $0.64 \mathrm{~cm}^{2} \mathrm{~d}^{-1}$ & $\mathrm{~T}$ & $\begin{array}{l}\text { Monti, Poc, Por, } \\
\text { Ser, Sty }\end{array}$ & 43 \\
\hline \multicolumn{7}{|l|}{ Vertebrates (114) } \\
\hline \multicolumn{7}{|l|}{ Chordata, Tetraodontiformes } \\
\hline \multicolumn{7}{|l|}{ Tetraodontidae (8) } \\
\hline Arothron hispidus & $\mathrm{B}, \mathrm{C}, \mathrm{E}, \mathrm{K}, \mathrm{L}, \mathrm{M}, \mathrm{N}$ & $\mathrm{F}$ & & $\mathrm{T}, \mathrm{S}$ & Poc & $4,47,48$ \\
\hline A. meleagris & $\mathrm{B}, \mathrm{C}, \mathrm{D}, \mathrm{E}, \mathrm{G}, \mathrm{H}, \mathrm{K}, \mathrm{L}$ & $\mathrm{F}$ & $10.13-16.38 \mathrm{~g} \mathrm{~d}^{-1}$ & $\mathrm{~T}, \mathrm{~S}$ & $\begin{array}{c}\text { Acr, Poc, Por, } \\
\text { Pav, Psa, Monti }\end{array}$ & $4,11,48-50$ \\
\hline A. nigropunctatus & $\mathrm{E}, \mathrm{F}, \mathrm{H}, \mathrm{I}, \mathrm{K}, \mathrm{L}, \mathrm{M}, \mathrm{N}$ & F & 1.73 bites $\min ^{-1}$ & $\mathrm{~T}, \mathrm{~S}$ & Acr, Pav, Poc, Por & $47,51,52$ \\
\hline A. stellatus & $\begin{array}{c}\mathrm{D}, \mathrm{E}, \mathrm{F}, \mathrm{G}, \mathrm{H}, \mathrm{I}, \mathrm{K}, \\
\mathrm{L}, \mathrm{M}, \mathrm{N}\end{array}$ & F & & $\mathrm{T}, \mathrm{S}$ & & 47,48 \\
\hline Canthigaster amboinensis & $\begin{array}{c}\mathrm{B}, \mathrm{C}, \mathrm{D}, \mathrm{E}, \mathrm{F}, \mathrm{G}, \\
\mathrm{H}, \mathrm{M}, \mathrm{N}\end{array}$ & F & $3.7 \%$ live coral diet & $\mathrm{T}, \mathrm{S}$ & & 48,53 \\
\hline C. jactator & $\mathrm{C}$ & $\mathrm{F}$ & $1.0 \%$ gut contents & $\mathrm{T}, \mathrm{S}$ & & 53 \\
\hline C. solandri & $\begin{array}{c}\mathrm{C}, \mathrm{E}, \mathrm{G}, \mathrm{K}, \mathrm{L} \\
\mathrm{M}, \mathrm{M}, \mathrm{N}\end{array}$ & F & $11.1 \%$ live coral diet & $\mathrm{T}, \mathrm{S}$ & & $53-55$ \\
\hline C. valentini & $\mathrm{B}, \mathrm{E}, \mathrm{F}, \mathrm{G}, \mathrm{H}, \mathrm{L}, \mathrm{N}$ & $\mathrm{F}$ & $0.06-3$ bites $\min ^{-1}$ & $\mathrm{~T}, \mathrm{~S}$ & Pav, Poc, Por & 52 \\
\hline \multicolumn{7}{|l|}{ Balistidae (7) } \\
\hline Balistapus undulatus & $\mathrm{D}, \mathrm{E}, \mathrm{F}, \mathrm{G}, \mathrm{I}, \mathrm{L}, \mathrm{M}, \mathrm{N}$ & F & 1.87 bites $\min ^{-1}$ & $\mathrm{~T}, \mathrm{~S}$ & Pav, Poc, Por & $47,48,52$ \\
\hline Balistes polyepis & $\mathrm{B}, \mathrm{C}$ & F & & $\mathrm{T}, \mathrm{S}$ & Pav, Por & 4 \\
\hline B. vetula & A, P & F & $0.2 \%$ gut contents & $\mathrm{T}, \mathrm{S}$ & & 56 \\
\hline Balistoides viridescens & $\mathrm{G}, \mathrm{M}, \mathrm{N}$ & F & & $\mathrm{T}, \mathrm{S}$ & & 47 \\
\hline Melichthys niger & $\begin{array}{c}\mathrm{A}, \mathrm{B}, \mathrm{C}, \mathrm{E}, \mathrm{G}, \mathrm{H}, \\
\mathrm{L}, \mathrm{M}, \mathrm{N}\end{array}$ & F & $0.6 \%$ gut contents & $\mathrm{T}, \mathrm{S}$ & $\mathrm{Col}$ & 56 \\
\hline Rhinecanthus aculeatus & $\mathrm{G}, \mathrm{I}, \mathrm{K}, \mathrm{L}, \mathrm{M}, \mathrm{N}$ & F & & $\mathrm{T}, \mathrm{S}$ & & 48 \\
\hline Sufflamen verres & $\mathrm{B}$ & F & & $\mathrm{T}, \mathrm{S}$ & Poc, Por, Pav & 4 \\
\hline \multicolumn{7}{|l|}{ Monacanthidae (5) } \\
\hline Amanses scopas & $\mathrm{E}, \mathrm{F}, \mathrm{G}, \mathrm{H}, \mathrm{I}, \mathrm{L}, \mathrm{N}$ & $\mathrm{O}$ & & $\mathrm{T}, \mathrm{S}$ & & 48 \\
\hline Cantherhines dumerilii & $\begin{array}{l}\mathrm{B}, \mathrm{D}, \mathrm{E}, \mathrm{F}, \mathrm{G} \\
\mathrm{L}, \mathrm{M}, \mathrm{N}\end{array}$ & $\mathrm{F}$ & & $\mathrm{T}, \mathrm{S}$ & $\begin{array}{l}\text { Acr, Poc, Monti, } \\
\text { Lep, Por }\end{array}$ & $47,48,50$ \\
\hline C. pullus & $\mathrm{A}$ & F & $0.7 \%$ gut contents & $\mathrm{T}, \mathrm{S}$ & & 56 \\
\hline C. sandwichiensis & $\mathrm{C}, \mathrm{D}$ & $\mathrm{F}$ & & $\mathrm{T}, \mathrm{S}$ & & 48 \\
\hline $\begin{array}{l}\text { Oxymonacanthus } \\
\text { longirostris }\end{array}$ & $\mathrm{E}, \mathrm{F}, \mathrm{G}, \mathrm{H}, \mathrm{L}, \mathrm{M}, \mathrm{N}$ & $\mathrm{O}$ & 10.5 bites $\mathrm{min}^{-1}$ & $\mathrm{M}, \mathrm{T}$ & Acr & $47,48,51,57$ \\
\hline
\end{tabular}


Appendix 1 (continued)

\begin{tabular}{|c|c|c|c|c|c|c|}
\hline Taxa & Region & $\begin{array}{l}\text { Feedin } \\
\text { mode }\end{array}$ & $\begin{array}{l}\text { Consumption } \\
\text { rate }\end{array}$ & Style & Coral prey & $\begin{array}{l}\text { Literature } \\
\text { cited }\end{array}$ \\
\hline \multicolumn{7}{|l|}{ Chordata, Perciformes } \\
\hline \multicolumn{7}{|l|}{ Gobiidae (1) } \\
\hline Gobiodon citrinus & $\mathrm{E}, \mathrm{F}, \mathrm{G}, \mathrm{H}, \mathrm{I}, \mathrm{L}, \mathrm{N}$ & $\mathrm{O}$ & $99 \%$ gut contents & $\mathrm{T}, \mathrm{M}$ & Acr & 51 \\
\hline \multicolumn{7}{|l|}{ Labridae (8) } \\
\hline Coris aygula & $\mathrm{G}, \mathrm{N}, \mathrm{O}$ & F & 0.13 bites $\min ^{-1}$ & $\mathrm{~T}$ & Pav, Poc, Por & 52 \\
\hline Diproctacanthus xanthurus & $\mathrm{E}, \mathrm{F}, \mathrm{G}$ & F & & $\mathrm{T}, \mathrm{S}$ & & 47 \\
\hline Gomphosus caeruleus & $\mathrm{N}$ & F & 0.13 bites $\min ^{-1}$ & $\mathrm{~T}$ & Pav, Poc, Por & 52 \\
\hline Labrichthys unilineatus & $\mathrm{E}, \mathrm{F}, \mathrm{G}, \mathrm{H}, \mathrm{L}, \mathrm{M}, \mathrm{N}$ & $\mathrm{O}$ & 1.9 bites $\min ^{-1}$ & $\mathrm{~T}, \mathrm{~S}$ & Acr, Monti & $47,48,51,58$ \\
\hline Labropsis australis & $\mathrm{E}, \mathrm{F}$ & $\mathrm{O}$ & & $\mathrm{T}, \mathrm{S}$ & & 47,48 \\
\hline L. polynesica & $\mathrm{E}$ & $\mathrm{O}$ & & $\mathrm{T}, \mathrm{S}$ & & 48 \\
\hline L. xanthonota & $\mathrm{E}, \mathrm{F}, \mathrm{G}, \mathrm{H}, \mathrm{L}, \mathrm{N}$ & $\mathrm{O}$ & & $\mathrm{T}, \mathrm{S}$ & & 48 \\
\hline Thalasomma lunare & $\mathrm{E}, \mathrm{F}, \mathrm{G}, \mathrm{H}, \mathrm{I}, \mathrm{L}, \mathrm{N}$ & $\mathrm{F}$ & 0.13 bites min $^{-1}$ & $\mathrm{~T}$ & Pav, Poc, Por & 52 \\
\hline \multicolumn{7}{|l|}{ Blennidae (1) } \\
\hline Exallias brevis & $\mathrm{G}, \mathrm{H}, \mathrm{K}, \mathrm{L}, \mathrm{M}, \mathrm{N}$ & F & $72 \%$ gut contents & $\mathrm{T}, \mathrm{S}$ & Acr & 47,51 \\
\hline \multicolumn{7}{|l|}{$\underline{\text { Scaridae (21) }}$} \\
\hline 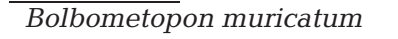 & $\mathrm{E}, \mathrm{F}, \mathrm{G}, \mathrm{H}, \mathrm{I}, \mathrm{L}, \mathrm{N}$ & F & 6.09 bites $\min ^{-1}$ & $\mathrm{~T}, \mathrm{~S}$ & Acr, Poc, Por, Mont & $47,48,59-61$ \\
\hline Calotomus carolinus & $\mathrm{B}, \mathrm{C}, \mathrm{D}, \mathrm{E}, \mathrm{F}, \mathrm{G}, \mathrm{H}, \mathrm{L}$ & F & 0.13 bites $\min ^{-1}$ & $\mathrm{~T}$ & Pav, Poc, Por & 52 \\
\hline Cetoscarus bicolor & $\mathrm{G}, \mathrm{L}$ & F & 0.4 bites $\min ^{-1}$ & $\mathrm{~T}, \mathrm{~S}$ & Por & 62 \\
\hline Chlororus gibbus & I & F & 1.1 bites $\min ^{-1}$ & $\mathrm{~T}, \mathrm{~S}$ & Por & $48,62,63$ \\
\hline C. microrhinos & $\mathrm{E}, \mathrm{F}, \mathrm{G}, \mathrm{H}$ & $\mathrm{F}$ & & $\mathrm{T}, \mathrm{S}$ & & 48,63 \\
\hline C. sordidus & $\mathrm{E}, \mathrm{F}, \mathrm{G}, \mathrm{I}, \mathrm{K}, \mathrm{L}, \mathrm{M}, \mathrm{N}$ & $\mathrm{F}$ & 2.2 bites $\min ^{-1}$ & $\mathrm{~T}, \mathrm{~S}$ & & 48,62 \\
\hline C. strongylocephalus & $\mathrm{G}, \mathrm{L}, \mathrm{N}$ & F & 0.26 bites $\min ^{-1}$ & $\mathrm{~T}, \mathrm{~S}$ & Pav, Poc, Por & 48,52 \\
\hline Scarus coelestinus & A & $\mathrm{F}$ & $0.2 \%$ gut contents & $\mathrm{T}, \mathrm{S}$ & & 56 \\
\hline S. frenatus & $E, F, G$ & $\mathrm{~F}$ & $<1 \%$ live coral diet & $\mathrm{T}, \mathrm{S}$ & Por & 84 \\
\hline S. guacamaia & $\mathrm{A}$ & F & & $\mathrm{T}, \mathrm{S}$ & & \\
\hline S. ghobban & $\mathrm{B}, \mathrm{D}, \mathrm{E}, \mathrm{F}, \mathrm{G}, \mathrm{H}, \mathrm{I}, \mathrm{K}, \mathrm{L}$ & $\mathrm{F}$ & & $\mathrm{T}, \mathrm{S}$ & Por & \\
\hline S. perrico & B & $\mathrm{F}$ & & $\mathrm{T}, \mathrm{S}$ & Poc & 4 \\
\hline S. perspicillatus & $\mathrm{C}$ & $\mathrm{F}$ & & $\mathrm{T}, \mathrm{S}$ & Por & 61 \\
\hline S. rivulatus & $\mathrm{E}, \mathrm{F}, \mathrm{G}, \mathrm{H}, \mathrm{O}$ & F & 1.7 bites $\min ^{-1}$ & $\mathrm{~T}, \mathrm{~S}$ & Por & 62 \\
\hline S. taeniopterus & A & $\mathrm{F}$ & & $\mathrm{T}, \mathrm{S}$ & Mad, Por & 64 \\
\hline S. trispinosus & $\mathrm{R}$ & $\mathrm{F}$ & $0.8 \%$ live coral diet & $\mathrm{T}, \mathrm{S}$ & Fav, Muss, Sid & 49 \\
\hline S. vetula & A & $\mathrm{F}$ & & $\mathrm{T}, \mathrm{S}$ & Monta, Sid & 64,65 \\
\hline S. viridifucatus & $\mathrm{L}$ & F & 0.2 bites $\min ^{-1}$ & $\mathrm{~T}, \mathrm{~S}$ & Pav, Poc, Por & 52 \\
\hline Sparisoma aurofrenatum & A & $\mathrm{F}$ & $0.2 \%$ gut contents & $\mathrm{T}, \mathrm{S}$ & Monta, Por, Mad & $56,64,65$ \\
\hline S. amplum & $\mathrm{R}$ & $\mathrm{F}$ & $8.1 \%$ live coral diet & $\mathrm{T}, \mathrm{S}$ & Fav, Muss, Sid & 49 \\
\hline S. viride & A & $\mathrm{F}$ & $25 \mathrm{~cm}^{2} \mathrm{~d}^{-1}$ & $\mathrm{~T}, \mathrm{~S}$ & $\begin{array}{l}\text { Col, Por, Monta, } \\
\text { Sid, Dip, Aga }\end{array}$ & $65-67$ \\
\hline \multicolumn{7}{|l|}{ Pomacanthidae (2) } \\
\hline Centropyge multispinus & $\mathrm{L}$ & $\mathrm{F}$ & 0.2 bites $\min ^{-1}$ & $\mathrm{~T}$ & Pav, Poc, Por & 52 \\
\hline Pomacanthus semicirculatus & $E, F, G$ & $\mathrm{~F}$ & $0.13-0.26$ bites $\min ^{-1}$ & $\mathrm{~T}$ & Pav, Poc, Por & 52 \\
\hline \multicolumn{7}{|l|}{ Pomacentridae (7) } \\
\hline Cheiloprion labiatus & $\mathrm{F}, \mathrm{G}, \mathrm{H}$ & $\mathrm{F}$ & $93 \%$ gut contents & $\mathrm{T}, \mathrm{S}$ & Acr & 51 \\
\hline Neoglyphidodon melas & I, G & $\mathrm{F}$ & & $\mathrm{T}$ & & 51 \\
\hline Pomacentrus leucostictus & A & $\mathrm{F}$ & $1.5 \%$ gut contents & $\mathrm{T}$ & & 56 \\
\hline P. variabilis & A & $\mathrm{F}$ & $1.7 \%$ gut contents & $\mathrm{T}$ & & 56 \\
\hline Plectroglyphidodon dickii & $D, E, F, G, H, L$ & $\mathrm{~F}$ & $37 \%$ gut contents & $\mathrm{T}$ & Acr. Poc & 51 \\
\hline P. johnstonianus & $C, D, F, G, H, L$ & $\mathrm{~F}$ & $96 \%$ gut contents & $\mathrm{M}, \mathrm{T}$ & Acr & 51 \\
\hline Stegastes planifrons & A & F & $0.6 \%$ gut contents & $\mathrm{T}$ & Acr, Monta & 56,68 \\
\hline \multicolumn{7}{|l|}{ Zanclidae (1) } \\
\hline $\begin{array}{l}\text { Zanclus canascens/ } \\
\text { cornutus }\end{array}$ & $\begin{array}{c}\mathrm{B}, \mathrm{C}, \mathrm{D}, \mathrm{E}, \mathrm{F}, \mathrm{G}, \\
\mathrm{L}, \mathrm{M}, \mathrm{N}\end{array}$ & $\mathrm{F}$ & 0.53 bites $\mathrm{min}^{-1}$ & $\mathrm{~T}, \mathrm{~S}$ & Pav, Por, Poc & 52 \\
\hline \multicolumn{7}{|l|}{ Chaetodontidae (53) } \\
\hline Chaetodon aculeatus & A & $\mathrm{F}$ & 0.43 bites $\min ^{-1}$ & $\mathrm{~T}$ & Aga, Monta, Sid & 69 \\
\hline C. andamanensis & $\mathrm{K}, \mathrm{M}, \mathrm{N}$ & $\mathrm{O}$ & & $\mathrm{T}$ & Acr & 70 \\
\hline C. aureofasciatus & $\mathrm{E}, \mathrm{F}, \mathrm{O}$ & $\mathrm{F}$ & & $\mathrm{T}$ & & 47,71 \\
\hline C. auriga & $\mathrm{E}, \mathrm{G}, \mathrm{H}, \mathrm{I}, \mathrm{L}, \mathrm{N}$ & $\mathrm{F}$ & $18-60 \%$ gut contents & $\mathrm{T}$ & & $47,51,71,72$ \\
\hline C. auripes & $\mathrm{H}$ & $\mathrm{F}$ & $12 \%$ gut contents & $\mathrm{T}$ & & 51 \\
\hline C. austriacus & I & $\mathrm{O}$ & $4.4-6.4$ bites $\min ^{-1}$ & $\mathrm{~T}$ & $\begin{array}{l}\text { Acr, Fav, Monti, Poc, } \\
\text { Por, Ser, Sty }\end{array}$ & $71,73-75$ \\
\hline
\end{tabular}


Appendix 1 (continued)

\begin{tabular}{|c|c|c|c|c|c|c|}
\hline Taxa & Region & $\begin{array}{r}\text { Feedin } \\
\text { mode }\end{array}$ & $\begin{array}{l}\text { Consumption } \\
\text { rate }\end{array}$ & Style & Coral prey & $\begin{array}{l}\text { Literature } \\
\text { cited }\end{array}$ \\
\hline C. baronessa & $\mathrm{E}, \mathrm{F}, \mathrm{G}, \mathrm{H}$ & $\mathrm{O}$ & & $\mathrm{T}$ & Acr & 47,51 \\
\hline C. bennetti & $\mathrm{D}, \mathrm{E}, \mathrm{F}, \mathrm{G}, \mathrm{H}, \mathrm{L}, \mathrm{M}$ & $\mathrm{O}$ & & $\mathrm{M}, \mathrm{T}$ & & 47,51 \\
\hline C. capistratus & $\mathrm{A}$ & $\mathrm{F}$ & 5.4 bites $\min ^{-1}$ & $\mathrm{~T}$ & Aga, Sid, Mad, Myc & 69,71 \\
\hline Chaetodon citrinellus & $C, D, E, G, H, L, M, N$ & $\mathrm{~F}$ & $15-19 \%$ gut contents & $\mathrm{T}$ & & $47,51,71,72$ \\
\hline C. ephippium & C, D, E, G, H & $\mathrm{F}$ & $19-26 \%$ gut contents & $\mathrm{T}$ & & $51,71,72$ \\
\hline C. falcula & $\mathrm{L}$ & $\mathrm{F}$ & 0.26 bites $\mathrm{min}^{-1}$ & $\mathrm{~T}$ & Pav, Poc, Por & 52,71 \\
\hline C. flavirostris & $\mathrm{D}, \mathrm{E}, \mathrm{F}$ & F & & $\mathrm{T}$ & & 47,48 \\
\hline C. guttatissimus & $\mathrm{L}$ & $\mathrm{F}$ & & $\mathrm{T}$ & & 71 \\
\hline C. kleinii & $\mathrm{C}, \mathrm{E}, \mathrm{G}, \mathrm{H}, \mathrm{I}, \mathrm{L}, \mathrm{N}$ & F & $3 \%$ gut contents & $\mathrm{T}$ & & $47,51,71$ \\
\hline C. larvatus & I & $\mathrm{O}$ & 10 bites $\min ^{-1}$ & $\mathrm{~T}$ & & 76 \\
\hline C. lineolatus & $\mathrm{E}, \mathrm{G}, \mathrm{I}, \mathrm{L}, \mathrm{N}$ & $\mathrm{F}$ & & $\mathrm{T}$ & & 47 \\
\hline C. lunula & $\mathrm{E}, \mathrm{F}, \mathrm{G}, \mathrm{L}, \mathrm{N}$ & $\mathrm{F}$ & 0.2 bites $\min ^{-1}$ & $\mathrm{~T}$ & Pav, Poc, Por & $47,52,71$ \\
\hline C. lunulatus & $\mathrm{C}, \mathrm{E}, \mathrm{F}, \mathrm{G}, \mathrm{H}, \mathrm{O}$ & $\mathrm{O}$ & & $\mathrm{T}$ & & 48 \\
\hline C. madagascariensis & L & $\mathrm{F}$ & & $\mathrm{T}$ & & 71 \\
\hline C. melannotus & $\mathrm{E}, \mathrm{F}, \mathrm{G}, \mathrm{H}, \mathrm{I}, \mathrm{L}, \mathrm{N}$ & $\mathrm{F}$ & $42 \%$ gut contents & $\mathrm{T}$ & & $47,51,71$ \\
\hline C. mertensii & $\mathrm{D}, \mathrm{E}, \mathrm{F}, \mathrm{G}, \mathrm{H}, \mathrm{L}$ & $\mathrm{F}$ & & $\mathrm{T}$ & & 71 \\
\hline C. mesoleucos & $\begin{array}{c}\text { I } \\
\text { I }\end{array}$ & $\mathrm{F}$ & 6 bites $\min ^{-1}$ & $\mathrm{~T}$ & & 76 \\
\hline C. meyeri & $\mathrm{F}, \mathrm{G}, \mathrm{H}, \mathrm{L}, \mathrm{M}, \mathrm{N}$ & $\mathrm{O}$ & & $\mathrm{T}$ & & 47,48 \\
\hline C. multicinctus & C & $\mathrm{F}$ & 21.8 bites $\min ^{-1}$ & $\mathrm{~T}$ & Poc, Por & 71,77 \\
\hline C. ocellatus & A & $\mathrm{F}$ & & $\mathrm{T}$ & $\mathrm{Acr}$ & 31 \\
\hline C. octofasciatus & $\mathrm{G}, \mathrm{H}$ & $\mathrm{O}$ & & $\mathrm{T}$ & Acr & 78 \\
\hline C. ornatissimus & $\mathrm{E}, \mathrm{F}, \mathrm{G}, \mathrm{N}, \mathrm{O}$ & $\mathrm{O}$ & $2.08-5.62$ bites $\mathrm{min}^{-1}$ & $\mathrm{M}, \mathrm{T}$ & Monti, Poc, Por & $51,71,79$ \\
\hline C. oxycephalus & $\mathrm{G}, \mathrm{N}, \mathrm{O}$ & $\mathrm{F}$ & & $\mathrm{T}$ & & 47 \\
\hline C. pelewensis & $\mathrm{D}, \mathrm{E}, \mathrm{F}$ & $\mathrm{F}$ & $58.9 \%$ gut contents & $\mathrm{T}$ & & $47,71,72$ \\
\hline C. plebeius & $\mathrm{E}, \mathrm{G}, \mathrm{H}, \mathrm{O}$ & $\mathrm{O}$ & & $\mathrm{T}$ & Acr & $47,51,71$ \\
\hline C. punctatofasciatus & $\mathrm{M}, \mathrm{N}$ & $\mathrm{F}$ & & $\mathrm{T}$ & $\mathrm{Poc}$ & 47,80 \\
\hline C. quadrimaculatus & $\mathrm{C}, \mathrm{D}, \mathrm{E}, \mathrm{G}, \mathrm{H}$ & $\mathrm{F}$ & $27.5 \%$ gut conents & $\mathrm{T}$ & $\mathrm{Poc}$ & $48,71,72$ \\
\hline C. rafflesii & $\mathrm{E}, \mathrm{F}, \mathrm{G}, \mathrm{H}, \mathrm{N}$ & F & $10 \%$ gut contents & $\mathrm{T}$ & & 47,51 \\
\hline C. rainfordi & $\mathrm{F}$ & $\mathrm{F}$ & & $\mathrm{T}$ & & 71 \\
\hline C. reticulatus & $\mathrm{E}, \mathrm{F}, \mathrm{G}, \mathrm{H}$ & $\mathrm{O}$ & & $\mathrm{T}$ & & 47,71 \\
\hline C. semilarvatus & G, H, I, N & $\mathrm{O}$ & 6 bites $\min ^{-1}$ & $\mathrm{~T}$ & & 76 \\
\hline C. smithi & $\mathrm{D}$ & $\mathrm{F}$ & & $\mathrm{T}$ & & 48 \\
\hline C. speculum & $\mathrm{E}, \mathrm{F}, \mathrm{G}, \mathrm{H}, \mathrm{N}, \mathrm{O}$ & $\mathrm{F}$ & $75 \%$ gut contents & $\mathrm{T}$ & & 47,51 \\
\hline C. striatus & A & $\mathrm{F}$ & & $\mathrm{T}$ & Acr & 31 \\
\hline C. triangulum & $\mathrm{N}$ & $\mathrm{O}$ & & $\mathrm{T}$ & & 71 \\
\hline C. trichrous & $\mathrm{D}$ & $\mathrm{F}$ & & $\mathrm{T}$ & & 48 \\
\hline C. trifascialis & $\mathrm{C}, \mathrm{E}, \mathrm{G}, \mathrm{H}, \mathrm{I}, \mathrm{L}, \mathrm{M}$ & $\mathrm{O}$ & $4.58-10.74$ bites $\min ^{-1}$ & $\mathrm{~T}$ & Acr, Poc, Por, Monti & $51,71,78,81$ \\
\hline C. trifasciatus & $\mathrm{C}, \mathrm{D}, \mathrm{E}, \mathrm{G}, \mathrm{H}, \mathrm{I}, \mathrm{L}, \mathrm{M}$ & $\mathrm{O}$ & $1.1-3.1$ bites $\min ^{-1}$ & $\mathrm{~T}$ & $\begin{array}{l}\text { Acr, Pav, Poc, } \\
\text { Por, Monti }\end{array}$ & $\begin{array}{c}47,51,52 \\
71,79\end{array}$ \\
\hline C. ulietensis & $\mathrm{E}, \mathrm{G}, \mathrm{H}$ & $\mathrm{F}$ & $10-69 \%$ gut contents & $\mathrm{T}$ & & 51,72 \\
\hline C. unimaculatus & $\mathrm{C}, \mathrm{D}, \mathrm{E}, \mathrm{G}, \mathrm{H}, \mathrm{L}, \mathrm{N}, \mathrm{O}$ & - & $4.9-7.2$ bites $\mathrm{min}^{-1}$ & $\mathrm{~T}$ & Monti, Poc & $47,51,71,82$ \\
\hline C. vagabundus & $\mathrm{E}, \mathrm{G}, \mathrm{H}, \mathrm{L}, \mathrm{M}, \mathrm{N}$ & F & $8-18 \%$ gut contents & $\mathrm{T}$ & & $51,71,72$ \\
\hline C. xanthocephalus & $\mathrm{L}$ & $\mathrm{F}$ & & $\mathrm{T}$ & & 71 \\
\hline Forcipiger flavissimus & $\mathrm{B}, \mathrm{E}, \mathrm{L}$ & $\mathrm{F}$ & $6.2 \%$ gut contents & $\mathrm{T}$ & & 72 \\
\hline Heniochus chrysostomus & $\mathrm{D}, \mathrm{E}, \mathrm{F}, \mathrm{G}, \mathrm{H}, \mathrm{O}$ & $\mathrm{F}$ & $7.1 \%$ gut contents & $\mathrm{T}$ & & $47,48,72$ \\
\hline H. intermedius & I & $\mathrm{F}$ & 1.3 bites min $^{-1}$ & $\mathrm{~T}$ & & 76 \\
\hline H. singularus & $\mathrm{E}, \mathrm{G}, \mathrm{H}$ & $\mathrm{F}$ & & $\mathrm{T}$ & & 48 \\
\hline H. varius & $\mathrm{E}, \mathrm{F}, \mathrm{H}, \mathrm{N}, \mathrm{O}$ & $\mathrm{F}$ & & $\mathrm{T}$ & & 48 \\
\hline
\end{tabular}


Appendix 2. References (Author, year) corresponding to reference numbers in Appendix 1

\begin{tabular}{|c|c|c|c|c|c|}
\hline No. & Corresponding reference & No. & Corresponding reference & No. & Corresponding reference \\
\hline 1 & Sussman et al. (2003) & 29 & Miller (2001) & 58 & McIlwain \& Jones (1997) \\
\hline 2 & Witman (1988) & 30 & Baums et al. (2003) & 59 & Choat (1991) \\
\hline 3 & Glynn (1980) & 31 & Brawley \& Adey (1982) & 60 & Bellwood et al. (2003) \\
\hline 4 & Glynn et al. (1972) & 32 & Ward (1965) & 61 & Randall (1974) \\
\hline 5 & Ross \& Newman (1969) & 33 & Oren et al. (1998) & 62 & Bellwood \& Choat (1990) \\
\hline 6 & Knudsen (1967) & 34 & Miller (1981) & 63 & Bellwood (1995) \\
\hline 7 & Glynn (1987) & 35 & Cumming (1999) & 64 & Frydl (1979) \\
\hline 8 & Rinkevich et al. (1991) & 36 & Kita et al. (2005) & 65 & Rotjan \& Lewis (2006) \\
\hline 9 & Castro (1978) & 37 & Turner (1994) & 66 & Rotjan \& Lewis (2005) \\
\hline 10 & Dana \& Wolfson (1970) & 38 & Ayling \& Ayling (1987) & 67 & Bruckner \& Bruckner (1998a) \\
\hline \multirow[t]{2}{*}{11} & Reyes-Bonilla \& & 39 & Moyer et al. (1982) & 68 & Kaufman (1977) \\
\hline & Calderon-Aguilera (1999) & 40 & Morton et al. (2002) & 69 & Neudecker (1985) \\
\hline 12 & Glynn (2004) & 41 & Bosch (1965) & 70 & Kuiter \& Debelius (1999) \\
\hline 13 & Colgan (1987) & 42 & Yokochi (2004) & 71 & Harmelin-Vivien (1989) \\
\hline 14 & Chess et al. (1997) & 43 & Guzman (1988) & 72 & Harmelin-Vivien \& \\
\hline 15 & Pearson \& Endean (1969) & 44 & Dall (1889) & & Bouchon-Navaro (1983) \\
\hline 16 & Glynn \& Krupp (1986) & 45 & Robertson et al. (1970) & 73 & Wrathall et al. (1992) \\
\hline 17 & Thomassin (1976) & 46 & Keen (1958) & 74 & Alwany et al. (2003) \\
\hline 18 & Glynn et al. (1983) & 47 & Randall et al. (1996) & 75 & Righton et al. (1998) \\
\hline 19 & Herring (1972) & 48 & Randall (2005) & 76 & Zekeria et al. (2002) \\
\hline 20 & Bak \& van Eys (1975) & 49 & Francini-Filho et al. (2008) & 77 & Tricas (1989) \\
\hline 21 & Glynn (1988) & 50 & Jayewardene \& Birkeland (2006) & 78 & Sadovy \& Cornish (2000) \\
\hline 22 & Glynn et al. (1979) & 51 & Sano et al. (1984) & 79 & Reese (1977) \\
\hline 23 & Griffin et al. (2003) & 52 & McClanahan et al. (2005) & 80 & Neudecker (1979) \\
\hline 24 & Ostergaard (1955) & 53 & Allen \& Randall (1977) & 81 & Irons (1989) \\
\hline 25 & Robertson (1970) & 54 & Acero \& Rivera (1992) & 82 & Cox (1986) \\
\hline 26 & Dalton \& Godwin (2006) & 55 & Harmelin-Vivien (1979) & 83 & Bruckner (2000) \\
\hline 27 & Ritson-Williams et al. (2003) & 56 & Randall (1967) & 84 & Hoey \& Bellwood (2008) \\
\hline 28 & Haramaty (1991) & 57 & Barlow (1987) & & \\
\hline
\end{tabular}

Editorial responsibility: Charles Birkeland, Honolulu, Hawaii, USA
Submitted: November 20, 2007; Accepted: April 22, 2008

Proofs received from author(s): August 26, 2008 